\title{
N a mira do olhar: um exercício de análise da fotografia nas revistas ilustradas cariocas, na primeira metade do século $X^{1}$
}

\author{
Ana Maria Mauad \\ Departamento de História da Universidade \\ Federal Fluminense e Laboratório \\ de História Oral e Imagem da UFF
}

RESUM 0 : Este artigo traz considerações sobre a análise histórica de imagens fotog ráficas, aplicando as propostas teórico-metodológicas apresentadas a uma série fotográfica composta pelas imagens de duas revistas ilustradas, $C$ a reta e 0 C ruzeiro, publicadas na cidade do Rio de Janeiro entre 1900 e 1960 . Por meio da análise da mensagem fotográfica relacionase a elaboração dos códigos de comportamento de classe às suas representações socia is. PALAVRAS-C HAVE: Fotografia. Revistas ilustradas. Rio de Janeiro. Careta. 0 C ruzeiro. Representações sociais.

ABSTRACT: This article presents a historical approach for the analysis of photographic images, followed by the application of these theoretical and methodological considerations to a series of photographs issued in two popular magazines, published in the city of Rio de Janeiro between 1900 and 1960 . Through the analysis of the photographic message, class behaviour codes are related to their social representations.

KEYW 0 RDS: Photography. Ilustrated M agazines. Rio de Janeiro. Careta. 0 C ruzeiro. Social Representations.

Ao longo da década de 1990, a produção historiográfica sobre a imagem, notadamente a fotografia, ampliou-se de forma significativa ${ }^{2}$ coordenando a problemática dos saberes de ordem técnica aos seus usos sociais. Tal movimento aliou-se a um investimento transdisciplinar que visou a superar os limites da análise histórica do gênero iconográfico, buscando em diferentes disciplinas das Ciências Sociais uma inspiração metodológica renovadora.

\begin{abstract}
1. Este trabalho inscrevese no projeto de pesquisa intitulado Através da imagem:memória e história do fotojornalismo no Brasil contemporâneo, financiado pelo CNPq (agosto 2002-fevereiro 2005), sendo também um dos resultados do estágio de pós-doutorado realizado, entre setembro de 2003 ejaneiro de 2004 , junto à equipe do Serviço de Documentação Textual e Iconografia do Museu Paulista composta pelas doutoras Solange F. Lima eVânia C. Carvalho.

2. Três trabalhos publicados ao longo dessa década são importantes referências para se mapear as transformações neste campo de estudos: CARVALHO, 1994, p. 253-300; TURAZZI, 1998; MAUAD, 2000.
\end{abstract}


0 presente artigo procura articular a discussão teórico-metodológica mais ampla, sobre visualidade e história, a uma análise mais apurada da linguagem fotográfica, relativa à modalidade de registro visual produzido pela mídia impressa. A escolha da série recaiu sobre as imagens fotográficas veiculadas em duas revistas ilustradas de críticas de costumes que circulavam na cidade do Rio de Janeiro, quando capital federal, durante mais de 50 anos, sã o elas: Careta e 0 Cruzeiro. Ta is fo to grafias compunham o circuito social da fotografia no $\mathrm{N}$ ovecentos, conjuntamente com aquelas concernentes a o espaço doméstico e íntimo das frações da classe dominante, no seu processo de a burguesa mento. Conjuga-se assim, a educação do olhar, promovida pela ampla circulação de determinados tipos de fotografias, à consolidação dos códigos de comportamento e representações socia is que passavam a regular as relações no processo de produção de sentido social hegemônico.

Como forma de sistematizar adequadamente tal proposta, dividi o artigo em duas partes: uma primeira voltada para a exposição dos quadros de a nálise histórico-semiótica de séries fo tográficas (sem a profundar na problemática ontológica da imagem fotográfica); e uma segunda, cujo objetivo, nos limites deste artigo, é o de aplicar tal análise a uma série específica de imagens composta pelas fotografias das llustradas.

\section{Primeira parte}

Desde as últimas décadas do século XIX a percepção visual do mundo foi marcada pela utiliza ção de dispositivos técnicos para a produção das imagens. A demanda social de imagens foi se ampliando ao longo do século XX a ponto de podermos contar a sua história por meio das imagens técnicas, notadamente, a fotografia. Sendo assim, as imagens técnicas em sua dimensão de documentos e monumentos da história contemporânea devem ser trabalhadas a partir da ampliação da noção de testemunho, à maneira de Bloch.

Tal procedimento engendra alguns desdobramentos teórico-metodológicos, dentre os quais realçamos os processos de produção de sentido na sociedade contemporânea, com destaque para o papel desempenhado pela tecnologia; a definição do circuito social da produção de imagens técnicas, enfatizando a historicidade dos regimes visuais; o papel dos sujeitos socia is como mediadores da produção cultural, compreendendo que a relação entre produtores e receptores de imagens se traduz numa negociação de sentidos e significados; e a capacidade narrativa das imagens técnicas, discutindo-se aí a dimensão temporal das imagens, os elementos definidores de uma linguagem eminentemente visual e por fim o diálogo estabelecido entre imagens técnicas e outros textos, tanto de caráter verbal como não-verbal, a partir do princípio de intertextualidade.

Desse conjunto de desdobramentos podemos sintetizar os três p rincipa is aspectos a o considerarmos as imagens visua is: 
A questão da produção - o dispositivo que media a relação entre 0 sujeito que olha e a imagem que elabora. Por meio dessa atividade de olhar ocorre a manipulação de um dispositivo de caráter tecnológico que possui determina das regras definidas historicamente.

A questão da recepção - associada ao valor a tribuído à imagem pela sociedade que a produz mas também a recebe. $\mathrm{N}$ a medida em que esse valor está mais ou menos balizado pelos efeitos de realismo da imagem, ele apontará para a conformação histórica de certo regime de visualidade. Portanto, se a questão da relação da ima gem com o seu referente e o grau de iconicidade dessa imagem é uma questão estética, seu julgamento (ou a propriação) tem a ver com as condições de recepção e de como, por meio dessa, a tribui-se valor à imagem: informativo, artístico, íntimo, etc.

A questão do produto - entende-se aí a imagem consubstanciada em matéria, a capacidade da imagem potencializar a matéria em si mesma, como objetivação de trabalho humano, resultado do processo de produção de sentido e relação sociais. Compreendida como resultante de uma relação entre sujeitos, a imagem visual engendra uma capacidade narrativa que se processa numa dada temporalidade. Estabelece, assim, um diálogo de sentidos com outras referências culturais de caráter verbal e não-verbal. As imagens nos contam histórias (fatos/ acontecimentos), a tualizam memórias, inventam vivências, imaginam a História.

Fo tografia, visualidade e conhecimento

A história da fotografia confunde-se com as diferentes abordagens que, em diversos momentos do pensamento ocidental, aplicou-se à imagem fotográfica. A idéia de que o que está impresso na fotografia é a realidade pura e simples já foi criticada por diferentes campos do conhecimento, desde a teoria da percepção a té a semiologia pós-estruturalista. A própria crítica à essência mimética da imagem fotográfica já envolve um exercício de interpretação dessa imagem, datado e, por conseguinte, historicamente determinado.

Percebendo tal problemática, o filósofo francês Philipe Dubois, no primeiro capítulo do seu já clássico livro 0 a to fotográfico, apresenta dois momentos dessa crítica ${ }^{3}$ :

A fotografia como transformação do real (o discurso do código e da desconstrução).

A fotografia como o vestígio de um real (o discurso do índice e da referência).

N o primeiro, a crítica fundamental residiria na ilusão a rquitetada pelos efeitos do realismo foto gráfico. A fo to grafia, segundo diferentes setores a ssocia dos a essa crítica, é um discurso feito a partir da realidade, descolando-se completamente dela à medida que criava a sua representação de acordo com uma série de códigos convencionados socialmente. Desde a crítica que
3. A discussão sobre o realismo fotográfico pode ser encontrada também em outros autores, no entanto, optei pela abordagem de Dubois pelo seu caráter sistemático. Para um aprofundamento da crítica ao realismo fotográfico ver BURGIN, 1982;TAGG, 1988; BARTHES, 1977, 1980; SONTAG, 1977 BOURDIEU, 1990; SOLO MON-GODEAU, 1991. 
desnaturaliza a imagem, segundo critérios perceptivos - a fotografia é bidimensional, plana, com cores que em nada reproduzem a realidade (quando não é em preto-e-branco), puramente visual, excluindo outras formas sensoriais como o olfato e 0 ta to -, até a crítica ao convencionalismo da visualidade ocidental tributária da perspectiva renascentista, incluindo-se aí to do um conjunto de "denúncias" contra a encenação fotográfica, a fotografia foi sendo considerada como mero efeito do real.

0 grande problema desse primeiro momento da crítica à imagem fotográfica, apontado por Dubois, é desconsiderar a realidade empírica que fundamenta os discursos imagéticos, operando, exclusivamente, sobre eles. $\mathrm{N}$ esse sentido, não haveria realidade fora dos discursos que a revelam.

Já a segunda postura crítica em relação a o realismo fotográfico ultrapassa os processos de desconstrução discursiva, retomando, em outro nível, a questão do referente, ou ainda da materialidade da imagem fotográfica. 0 ponto de partida é compreender a natureza técnica do a to fotográfico, a sua característica de marca luminosa, daí a idéia de indício, de resíduo da realidade sensível impressa na imagem fotográfica. Em virtude desse princípio, a fotografia é considerada como testemunho: a testa a existência de uma realidade. Como corolário desse momento de inscrição do mundo na superfície sensível, seguemse as convenções e opções culturais historicamente rea lizadas.

Portanto, o segundo passo é entender que entre o objeto e a sua representação fotográfica interpõe-se uma série de ações convencionalizadas, tanto cultural como historicamente. A final de contas, existe uma diferença bastante significativa entre uma carte de visite e um instantâneo fotográfico de hoje. Por fim, há de se considerar a fotografia como uma determinada escolha realizada num conjunto de escolhas possíveis, guardando nessa atitude uma relação estreita com a visão de mundo daquele que aperta o botão e faz clique.

É, justamente, por considerar todos esses aspectos, que as fotografias nos imp ressionam, nos comovem, nos incomodam, enfim imprimem em nosso espírito sentimentos diferentes. Cotidia na mente, consumimos ima gens fo tog ráficas em jorna is e revistas que, com o seu poder de comunicação, to rnam-se emblemas de acontecimentos, como aquela já famosa foto da menina vietnamita correndo com o corpo queimado de napalm, durante a Guerra do Vietnã. A simples menção da foto já nos remete aos fatos e aos seus resultados.

Por outro lado, também faz parte da nossa prática de vida fotografar nossos filhos, nossos momentos importantes e os não tão significativos. Um elenco de temas que vai desde os rituais de passagem até os fragmentos do dia-a-dia no crescimento das crianças. Apreciamos fotografias, as colecionamos, organizamos álbuns fotográficos, em que narrativas engendram memórias. Em ambos os casos é a marca da existência das pessoas conhecidas e dos fatos ocorridos que salta aos olhos e nos faz falar "O lha só como ele cresceu!", ao vermos a foto recém-chegada da revelação.

Desde a sua descoberta até os dias de hoje, a fotografia vem acompanhando o mundo contemporâneo, registrando sua história numa linguagem de imagens. Uma história múltipla, constituída porgrandes e pequenos 
eventos, por personalidades mundiais e gente anônima, por lugares distantes e exóticos e pela intimidade doméstica, pelas sensibilidades coletivas e ideologias oficiais. N o entanto, a fotografia lança ao historiador um desafio: como chegar ao que não foi imediatamente revelado pelo olhar fotográfico? Como ultrapassar a superfície da mensa gem fotográfica e, do mesmo modo que Alice nos espelhos, ver a tra vés da imagem?

H istória e imagem, problemas e soluções possíveis

$\mathrm{N}$ ão é de hoje que a história proclamou sua independência dos textos escritos. A necessidade dos historiadores em problematizar temas pouco trabalhados pela historiografia tradicional levou-os a ampliar seu universo de fontes, bem como a desenvolver abordagens pouco convencionais à medida que se aproximavam das demais Ciências Sociais em busca de uma história total. N ovos temas passaram a fazer parte do elenco de objetos do historiador, dentre eles a vida privada, o cotidiano, as relações interpessoais, etc. Uma microhistória que, para ser narrada, não necessita perder a dimensão macro, social e to talizadora das relações sociais. N esse contexto, uma história social da família, da criança, do casamento, da morte etc. passou a ser contada, demandando, para tanto, muito mais informações que os inventários, testa mentos, curatela de menores, enfim, tudo o que uma documentação cartorial poderia oferecer. A tradição oral, os diários íntimos, a iconografia e a literatura a presentaram-se como fontes históricas da excelência das anteriores, mas que demandavam do historiador uma habilidade de interpretação com a qual não estava a parelhado. Tornava-se imprescindível que as antigas fronteiras e os limites tradiciona is fossem superados. Exigiu-se do historiador que ele fosse também antropólogo, sociólogo, semiólogo e um excelente detetive para aprender a relativizar, desvendar redes socia is, comp reender lingua gens, decodifica r sistemas de signos e decifrar vestígios, sem perder, jamais, a visão do conjunto.

$M$ ichel Vovelle, na primeira parte de Ideologias e mentalidades, discute a relação entre iconografia e história das mentalidades, destacando a sua utilização por parte dos historiadores da Idade M édia que - ao analisarem exvotos, altares, estátuas, etc. - buscaram traçar tanto uma geografia do sagrado como o perfil das sensibilidades coletivas no passado. As questões levantadas por Vovelle convergem para uma única questão: "Pode-se, efetivamente, elaborar uma verdadeira semiologia da imagem?"4.

A essa pergunta o coro de respostas não é unívoco, muito menos consensual, e engloba propostas das mais diversas, incluindo o estudo do mito, o trabalho lingüístico, a abordagem filosófica, a avaliação estética e a discussã 0 sobre o tipo de mensagem que as iconografias transmitem, segundo a abordagem da comunicação, métodos quantitativos, etc.

$\mathrm{N}$ esse âmbito, como no anterior, a diversidade converge para um ponto único: a questão da grade interpretativa. Q ue unidades comporiam a 
5.VOVELLE, 1987, p.102.

6. KNOWLES; SWEETEMAN, 2004. Em especial o balanço realizado na introdução do volume.

7. MENESES, 2003, p. 31. grade de interpretação das imagens do passado? Mais uma vez, tal como no jogo infantil de encaixe, ao tirarmos uma caixa encontramos outra. Cabe, portanto, as perguntas: como interpretar as imagens produzidas no passado? Q ual a natureza da produção imagética? Essa produção é invariá vel ou possui condicionantes históricos? Será a imagem das pinturas, dos desenhos, da estatuária sagrada, dos vitrais das capelas medievais, da mesma natureza que as imagens técnicas, a exemplo das do cinema e da fotografia? São esses questiona mentos que complicam e enriquecem o traba lho do historia dor dedica do à análise de fontes não-verbais. Dessa forma, como bem aponta M ichel Vovelle, "as interrogações que hoje se colocam são antes uma prova de saúde do que de enfermidade"

Da publicação do clássico trabalho de M ichel Vovelle até hoje, 0 campo de estudos sobre a visualidade a partir de uma abordagem histórica se a mpliou de forma considerável tanto internacional como nacionalmente. $\mathrm{N} 0$ âmbito internacional, registra-se a publicação, ao longo da década de 1990 , de um número significativo de trabalhos sobre o campo da cultura visual, com aborda gens inter e transd iscip linares ${ }^{6}$. Em termos das diretrizes da a tual produçã 0 acadêmica no campo das Ciências Humanas, um excelente balanço foi feito recentemente pelo historiador Ulpiano T. Bezerra de M eneses, do qual se destaca a defesa por uma História Visual, cujo horizonte teórico-metodológico configurase em torno de três dimensões: visual, visível e visão, considerados elementos definidores da visualidade, historicamente concebida como o conjunto de práticas e discursos associado às distintas formas de experiência visual ${ }^{7}$.

$\mathrm{N}$ o que diz respeito à fotografia, a lgumas situações merecem atenção especial. Tópicos que envolvem tanto a natureza técnica da imagem fotográfica como o próprio ato de fotografar, apreciar e consumir fotografias, entendendose esse processo como o circuito social da fotografia. Deve-se acrescentar ainda, é claro, os problemas relativos à a nálise do conteúdo da mensagem fo to gráfica que envolvem questões específicas a os elementos constitutivos dessa mensagem: existe a possibilidade de segmentar o contínuo da imagem? Em caso afirmativo, qual a natureza das unidades significantes que estruturam a mensagem fotográfica? Entendendo-se a fotografia como mensagem, qua is os níveis que a ind ividua liza riam?

Para tentar solucionar esse feixe de dúvidas há de se assumir uma proposta transdisciplinar. A aproximação da História com a Antropologia e Sociologia é bastante profícua. Em relação à Antropologia destacam-se algumas importantes contribuições como a abordagem antropológica do conceito de cultura, o estudo da dimensão simbólica das diversas práticas cotidianas, a análise da extensão ideal das práticas materiais, etc.

Ta is preocupações estão associadas a uma perspectiva sociológica que distingue, entre outros aspectos, a importância em considerar a dimensão de classe da produção simbólica, bem como o papel da ideologia na composição de mensagens socialmente significativas e da hegemonia como processo de disputa social que se estende à produção da imagem. N ão se deve descartar também o fato de que a avaliação das redes sociais da fotografia envolve uma 
abordagem em que produtores e consumidores da imagem fotográfica possuem um locus social definido.

Tudo isso está a liado à necessidade de se analisar o conteúdo da mensagem fotográfica que demanda, por sua vez, conceitos de disciplinas, cujo diálogo não se faz com a freqüência das acima indicadas, compondo, assim, metodologias coordenadas, ta is como uma abordagem histórico-semiótica da fotografia.

N essa perspectiva, a fotografia é interpretada como resultado de um trabalho social de produção de sentido, pautado sobre códig os convencionalizados culturalmente. É uma mensagem que se processa através do tempo, cujas unidades constituintes são culturais, mas assumem funções sígnicas diferenciadas, de acordo tanto com o contexto no qual a mensagem é veiculada quanto com o local que ocupam no interior da própria mensagem ${ }^{8}$. Estabelecem-se, assim, não apenas uma relação sintagmática, à medida que veicula um significado organizado, segundo as regras da produção de sentido nas linguagens não-verbais, mas também uma relação paradigmática, pois a representação final é sempre uma escolha realizada num conjunto de escolhas possíveis.

Portanto, ao redimensionar o papel da interpretação dos conceitos, conjugando uma série de disciplinas na elaboração da análise, a abordagem das mensagens visuais é transdisciplinar. $N$ esse sentido, se é a associação da História à Antropologia ou à Sociologia (ou às duas juntas) que indaga sobre as maneiras de ser e agir no passado, é a Semiótica que oferece mecanismos para o desenvolvimento da análise e permite a compreensão da produção de sentido nas sociedades humanas como uma totalidade para além da fragmentação habitual que a prática científica imprime.

Dessa forma, para a análise das ideologias, mentalidades ou práticas culturais, a utilização de fontes não-verbais deve ter em pauta o imperativo metodológico, sugerido pelo historiador americano Robert Darnton:

ao invés de confiar na intuição numa tentativa de invocar um vago clima de opinião, seria o caso de tomar pelo menos uma disciplina sólida dentro das ciências sociais e utilizá-la para relacionar a experiência mental com as realidades sociais e econômicas ${ }^{9}$.

A conjunção de uma problemática histórica, no trabalho com fotografias, e a procedência variada de olhares e abordagens que vêm sendo implementadas no tra to com a imagem visual resulta ram no surgimento de questões recorrentes a os diferentes traba lhos publicad os a tua Imente ${ }^{10}$. A partir da avaliação da produção recente, é possível estabelecer três premissas para o tra tamento crítico das imagens fotográficas do passado e do presente, a saber:

A noção de série ou coleção. Evidencia-se na produção contemporânea como a fotografia para ser trabalhada de forma crítica não pode ficar limitada a um simples exemplar. A noção de exemplo foi superada pela dinâmica da série que estabelece contatos diferenciados com distintos sup ortes da cultura material. Assim, a idéia da série extensa e homogênea foi tornada complexa pela noção de coleção, que rompe com a homogeneidade, demandando ao pesquisador
8. MAUAD, 1990.

9. DARNTON, 1990, p. 254.

10. Para uma avaliação precisa desse movimento de renovação do trabaIho com imagens fotográficas, cf. MAUAD 2000 p. 6-229. 
11. Um estudo consolidado sobre cinco instituições de guarda de acervos fotográficos pode ser encontrado no meu relatório de pós-doutorado publicado em http:// w w w.historia.uff.br/labhoi/ofic.htm

12. CARVALHO; LIMA 2000, p. 24. uma metodologia que considere seu caráter polifônico, resultante do circuito social de produção, circulação e consumo de imagens.

0 princípio de intertextua lidade. C omo corolário da primeira premissa depreende-se que uma fotografia, para ser interpretada como texto (suporte de relações sociais), demanda o conhecimento de outros textos que a precedem ou que com ela concorrem para a produção da textualidade de uma época. Sendo assim, 0 uso de fotografias como fonte histórica obriga tanto as instituições de guarda quanto os historiadores a o levantamento da cultura histórica, que institui os códigos de representação homologadores das imagens fotográficas no processo continuado de produção de sentido social.

0 trabalho transdisciplinar. 0 resultado da revolução documental dos anos 1960 foi a transformação da consciência historiográfica, expressa na aproximação efetiva da História com as diferentes disciplinas das $\mathrm{C}$ iências Sociais. N esse sentido, a compreensão da fotografia como uma mensagem significativa que se processa através do tempo, dialogando reiteradamente com os elementos da cultura material que a produz, demanda por parte do historiador um aparato teórico-metodológico que a crítica tradicional não habilitava, obrigando-0 ao desenvolvimento de novos questionamentos e procedimentos em perfeita coordenação com outros saberes.

Por fim, complementando o inventário de desafios e possibilidades da relação entre história e imagem, especificamente a fo tográfica, cabe fazer uma breve referência às condições de acesso às coleções sob a guarda de instituições de pesquisa - institutos, bibliotecas, museus e arquivos ${ }^{11}$. Em termos gerais, ainda existe uma forte resistência ou ceticismo em relação à possibilidade de estabelecimento de um vocabulário adequado à natureza visual da fotografia, o que corrobora a conclusão tirada pelas pesquisadoras do M useu Paulista, Solange Lima e Vânia Carvalho:

Apesar dos avanços já empreendidos, os critérios de seleção e montagem das formas descritivas da imagem ainda deixam muito a desejar quando se trata de atender às necessidades de produção de conhecimento sobre a própria fotografia. A ausência de descritores voltados para os a tributos formais da imagem é um dos problemas que merece destaque. 0 grau de estandardização dos termos descritivos do conteúdo visual deve levar em conta o perfil do público consulente, muitas vezes heterogêneo, e a tendência de integração das informações em redes internacionais. $\mathrm{N} o$ entanto, não nos parece que a necessidade de descritores genéricos deva comprometer as particularidades das coleções instituciona is, muito menos ignorar as expectativas do especialista ou os próprios a tributos da fotografia ${ }^{12}$.

Fotografia, história e os usos do passado

A fotog rafia é uma fonte histórica que demanda por parte do historiador um novo tipo de crítica. 0 testemunho é válido, não importando se o registro fotográfico foi feito para documentar um fato ou representar um estilo de vida. $\mathrm{N} 0$ 
entanto, parafraseando Jacques Le Goff, há de se considerar a fotografia simultaneamente como imagem/ documento e como imagem/ monumento. N o primeiro caso, considera-se a fotografia como índice, como marca de uma materialidade passada, na qual objetos, pessoas e lugares nos informam sobre determinados aspectos desse passado - condições de vida, moda, infra estrutura urbana ou rural, condições de trabalho, etc. $\mathrm{N}$ o segundo caso, a fotografia é um símbolo, a quilo que, no passado, a sociedade estabeleceu como a única imagem a ser perenizada para o futuro. Sem esquecer jamais que todo documento é monumento, se a fotografia informa, ela também conforma uma determinada visão de mundo.

Tal perspectiva remete ao circuito social da foto grafia ${ }^{13}$ nos diferentes períodos de sua história, incluindo-se, nessa categoria, todo o processo de produção, circula ção e consumo das imagens fo tog ráficas. Só assim será possível restabelecer as condições de emissão e recepção da mensagem fo to gráfica, bem como as tensões sociais que envolveram a sua elaboração. Dessa maneira, texto e contexto estarão contemplados.

O s textos visuais, inclusive a fotografia, são resultado de um jogo de exp ressão e conteúdo que envolvem, necessariamente, três componentes: 0 a utor, 0 texto propriamente dito e 0 leitor ${ }^{14}$. C ada um desses três elementos integra 0 resultado final à medida que to do o produto cultural envolve um locus de produção e um produtor, que manipula técnicas e detém saberes específicos à sua a tividade, um leitor ou destina tário, concebido como um sujeito transindividual cujas respostas estão diretamente liga das às p rogramações socia is de comporta mento do contexto histórico no qual se insere, e, por fim, um significado aceito socialmente como válido, resultante do trabalho de investimento de sentido.

No caso da fotografia, é evidente o papel de autor imputado ao fotógrafo. Porém, há de se concebê-lo como uma categoria social, seja profissional autônomo, fotógrafo de imprensa, oficial ou um mero amador "batedor de chapas". O grau de controle da técnica e das estéticas fotográficas variará na mesma proporção dos objetivos estabelecidos para a imagem final. Ainda assim, o controle de uma câmara fotográfica impõe uma competência mínima, por parte do autor, ligada fundamentalmente à manipulação de códigos convenciona dos social e historicamente para a produção de uma imagem possível de ser compreendida. N o século XIX, esse controle ficava restrito a um grupo seleto de fotógrafos profissionais que manipulava aparelhos pesados e tinha de produzir o seu próprio material de trabalho, inclusive a sensibilização de chapas de vidro. Com o desenvolvimento da indústria óptica e química, ainda no final dos 0 itocentos, ocorreu uma estandardização dos produtos fo to gráficos e uma compactação das câmaras, possibilitando uma ampliação do número de profissionais e usuários da fotografia. $\mathrm{N}$ o início do século XX, já era possível contar com as indústrias Kodak e a máxima da fotografia amadora: "You press the botton, we do the rest."

É importante levar em conta também que o controle dos meios técnicos de produção cultural envolve tanto aquele que detém o meio quanto o grupo ao qual ele serve, caso seja um fotógrafo profissional. N esse sentido, não seria exagero a firmar que o controle dos meios técnicos de produção cultural, a té por volta da década de 1950, foi privilégio da classe dominante ou frações dessa. 
Paralelamente ao processo de desenvolvimento tecnológico, o campo fotográfico foi sendo constituído a partir do estabelecimento de uma estética que incluía desde profissionais do retrato em busca da feição mais harmoniosa para seu cliente e o paisagista que buscava a nitidez da imagem e a amplitude de planos até o fotógrafo amador-artista, geralmente ligado às associações fotoclubísticas, que defendia a fotografia como expressão artística, baseada nos mesmos cânones que a pintura (por isso, não poupava a imagem fo tográfica de uma intervenção direta, tanto por meio do uso de filtros quanto do retoque, entre outras técnicas). Técnica e estética eram competência do autor.

À competência do autor corresponde a do leitor, cuja exigência mínima é saber que uma fotografia é uma fotografia, ou seja, o suporte material de uma imagem. $\mathrm{N}$ a verdade é a competência de quem olha que fornece significados à imagem. Essa compreensão se dá a partir de regras culturais, que fornecem a garantia para que a leitura da imagem não se limite a um sujeito individual, mas que a cima de tudo seja coletiva. A idéia de competência do leitor pressupõe que, na qualidade de destinatário da mensagem fotográfica, ele detenha uma série de saberes que envolvem outros textos sociais. A compreensão da imagem fotográfica, pelo leitor/ destinatário, dá-se em dois níveis, a saber:

- $N$ ível interno à superfície do texto visual, originado a partir das estrutura s espacia is que constituem tal texto, de ca rá ter nã 0 -verbal.

- N ível externo à superfície do texto visual, originado a partir de a proximações e inferências com outros textos da mesma época, inclusive de natureza verbal. $\mathrm{N}$ esse nível, pode-se descobrir temas conhecidos e inferir informações implícitas.

É importante destacar que a compreensão de textos visua is é tanto um a to conceitual (os níveis externo e interno encontram-se necessariamente em correspondência no processo de conhecimento) quanto um ato fundado numa pragmática, que pressupõe a aplicação de regras culturalmente a ceitas como válidas e convencionalizadas na dinâmica social. Percepção e interpretação são faces de um mesmo processo: o da educação do olhar. Existem regras de leitura dos textos visuais que são compartilhadas pela comunidade de leitores. Ta is regras não são gerada s esp ontaneamente; na verdade, resultam de uma disputa pelo significado adequado à s representa ções cultura is. Sendo assim, sua a plicação por parte dos leitores/ destinatários envolve, também, a situação de recepção dos textos visuais. Essa situação va ria historicamente, desde o veículo que suporta a imagem até a sua circulação e consumo, passando pelo controle dos meios técnicos de produção cultural, exercido por diferentes grupos que se enfrentam na dinâmica social. Portanto, se a cultura comunica, a ideologia estrutura a comunicação, e a hegemonia social faz com que a imagem da classe dominante predomine, erigindo-se como modelo para as demais.

$\mathrm{N}$ o caso da fotografia, os veículos incluem desde os tradicionais álbuns de retra to a té os bytes de uma imagem digitalizada, podendo a circulação limita r-se a o a mbiente familiar ou a mpliar seus caminhos na vegando pela Internet. Já a situação de consumo é direcionada para um destinatário: um apaixonado que guarda o retra to de sua a mada como uma relíquia ou um banco de memória 
que armazenará a imagem fotográfica a té que alguém acesse a informação e assuma o papel de leitor/ destinatário.

$\mathrm{N}$ a qualidade de texto, que pressupõe competências para sua produção e leitura, a fotografia deve ser concebida como uma mensagem que se organiza a partir de dois segmentos: expressão e conteúdo. 0 primeiro envolve escolhas técnicas e estéticas, como enquadra mento, ilumina çã 0 , definiçã 0 da imagem, contraste, cor, etc. Já o segundo é determinado pelo conjunto de pessoas, objetos, lugares e vivências que compõe a fotografia. Ambos os segmentos se correspondem no processo contínuo de produção de sentido na fotografia, sendo possível separá-los para fins de a nálise, mas compreendê-los somente como um todo integrado.

Historicamente, a fotografia forma, com outros tipos de texto de caráter verbal e não-verbal, a textualidade de uma determinada época. Tal idéia implica a noção de intertextualidade para a compreensão ampla das maneiras de ser e a gir de certo contexto histórico: à medida que os textos históricos não são a utônomos, necessitam de outros para sua interpretação. Da mesma forma, a fotografia - para ser utilizada como fonte histórica, ultrapassando seu mero aspecto ilustrativo - deve compor uma série extensa e homogênea para dar conta das semelhanças e diferenças próp rias a o conjunto de imagens que se escolheu analisar. $\mathrm{N}$ esse sentido, o corpus fotográfico pode ser organizado em função de um tema, como a morte, a criança, o casamento, etc., ou em função das diferentes a gências de produção da imagem que competem nos processos de produção de sentido social, entre as quais a família, o Estado, a imprensa e a publicidade. Em ambos os casos, a a nálise histórica da mensagem fotográfica tem na noção de espaço a sua chave de leitura, posto que a própria fotografia é um recorte espacial que contém outros espaços que a determinam e estruturam, como, por exemplo, o espaço geográfico, dos objetos (interiores, exteriores e pessoais), da figuração e das vivências, comportamentos e representações sociais.

Do ponto de vista temporal, a imagem fotográfica permite a presentificação do passado, como uma mensagem que se processa a través do tempo, colocando, por conseguinte, um novo problema ao historiador que, além de lidar com as competências a cima referidas, deve lidar com a sua própria competência, na situação de um leitor de imagens do passado. Retomamos, nesse ponto, a pergunta anterior: como olhar através das imagens? Por tudo que já foi dito, considerando-se a fotografia como uma fonte histórica que demanda um novo tipo de crítica, uma nova postura teórica de caráter transdisciplinar, a lgumas pistas para responder tal questão já foram dadas. Resta, no entanto, indicar, nessa ca deia de tempora lidades, qual o locus interpretativo do historia dor.

Já foi dito que as imagens são históricas e dependem das variáveis técnicas e estéticas do contexto histórico que as produziram e das diferentes visões de mundo concorrentes no jogo das relações sociais. N esse sentido, as fotografias guardam, na sua superfície sensível, a marca indefectível do passado que as produziu e consumiu. Um dia já foram memória presente, próxima àqueles que as possuíam, as guardavam e colecionavam como relíquias, lembranças ou testemunhos. N o processo de constante vir a ser, recuperam o seu caráter de presença num novo lugar, num outro contexto e com uma função diferente. Da mesma forma que seus antigos donos, o historiador entra em conta to com esse 
presente/ passado e o investe de sentido, um sentido diverso daquele dado pelos contemporâneos da imagem, mas próprio à problemática a ser estudada. Aí reside a competência daquele que analisa imagens do passado: no problema proposto e na construção do objeto de estudo. A imagem não fala por si só; é necessário que as perguntas sejam feitas.

\section{0 lhando através da imagem}

Todas essas reflexões inspiraram a elaboração de uma abordagem histórico-semiótica que, sem a pretensão de ser definitiva, vem sendo aplicada, com sucesso, em diferentes tipos de fotografias.

A fotografia deve ser considerada como produto cultural, fruto de trabalho social de produção sígnica. N esse sentido, toda a produção da mensagem fotográfica está associada aos meios técnicos de produção cultural. Dentro dessa perspectiva, a fotografia pode, por um lado, contribuir para a veicula ção de novos comportamentos e representações da classe que possui 0 controle de tais meios, e, por outro, atuar como eficiente meio de controle social por meio da educação do olhar.

Partindo-se dessa premissa, a fotografia não é apenas documento, mas também, monumento e, como toda a fonte histórica, deve passar pelos trâmites das críticas externa e interna para depois ser organizada em séries fo to gráficas, obedecendo a certa cronologia. Tais séries devem ser extensas, capazes de dar conta de um universo significativo de imagens, e homogêneas, posto que numa mesma série fotográfica há de se observar um critério de seleção, evitando-se misturar diferentes tipos de fotografia. Por exemplo, pode-se trabalhar com álbuns de família e revistas ilustradas para recuperar os códigos de representações socia is e programações de comportamento de certa classe social, num dado período histórico; no entanto, cada tipo de fotografia compõe uma série que deve ser trabalhada separadamente. Feito isso, parte-se para a análise do material.

0 primeiro passo é entender que, numa dada sociedade, coexistem e se articulam múltiplos códigos e níveis de codificação, que fornecem significa do a o universo cultural dessa mesma sociedade. 0 s códigos são elaborados na prática social e não podem nunca ser vistos como entidades ahistóricas.

0 segundo passo é conceber a fotografia como resultado de um processo de construção de sentido. Assim formada, ela nos revela, por meio do estudo da produção da imagem, uma pista para se chegar ao que não está aparente ao primeiro olhar, mas que concede sentido social à foto.

A fotografia comunica-se por meio de mensagens não-verbais, cujo signo constitutivo é a imagem. Portanto, sendo a produção da imagem um trabalho humano de comunicação, pauta-se, enquanto tal, em códigos convencionados socialmente, possuindo um caráter conotativo que remete às formas de ser e agir do contexto no qual está inserida como mensagens.

0 terceiro passo é perceber que a relação a cima proposta não é automática, posto que entre 0 sujeito que olha e a imagem que elabora existe to do um processo de investimento de sentido que deve ser avaliado. Portanto, 
para se ultrapassar o mero analogon da realidade, tal como a fotografia é concebida pelo senso comum, há de se atentar para alguns pontos. 0 primeiro deles diz respeito à relação entre signo e imagem. $\mathrm{N}$ ormalmente caracteriza-se a imagem como algo "natural", ou seja, algo inerente à própria natureza, e o signo como uma representação simbólica. Tal distinção é um falso problema para a a nálise semiótica, tendo em vista que a imagem pode ser concebida como um texto icônico que antes de depender de um código é algo que institui um código. Assim, no contexto da mensagem veiculada, a imagem - ao assumir o lugarde um objeto, de um a contecimento ou ainda de um sentimento - incorpora funções sígnicas.

Um segundo ponto remete à imagem fotográfica como mensagem, estruturada a partir de uma dupla referência: a si mesma (como escolha efetivamente realizada) e àquele conjunto de escolhas possíveis, não efetuadas, que se acham em relação de equivalência ou oposição com as escolhas efetuadas. Dito em outras palavras, deve-se compreender a fotografia como uma escolha efetuada em um conjunto de escolhas então possíveis.

Finalmente, o terceiro ponto concerne à relação entre o plano do conteúdo e o plano da expressão. Enquanto o primeiro leva em consideração a relação dos elementos da fotografia com o contexto no qual se insere, remetendose ao corte temático e temporal, o segundo pressupõe a compreensão das opções técnicas e estéticas, as quais, por sua vez, envolvem um aprendizado historicamente determinado que, como toda a pedagogia, é pleno de sentido social.

A partir desses três pontos, foram organizadas duas fichas de análise no intuito de decompor a imagem fotográfica em unidades culturais, gua rdandose a devida distinção entre forma do conteúdo e forma da expressão.

Ficha de elementos da forma do conteúdo

\begin{tabular}{|l|l|l|l|l|}
\hline $\begin{array}{l}\text { Agência produtora } \\
\text { Ano }\end{array}$ & & & & \\
\hline Local retratado & & & & \\
\hline Tema retratado & & & & \\
\hline Pessoas retratadas & & & & \\
\hline O bjetos retratados & & & & \\
\hline Atributo das pessoas & & & & \\
\hline Atributo da paisagem & & & & \\
\hline $\begin{array}{l}\text { Tempo retratado } \\
\text { (dia/ noite) }\end{array}$ & & & & \\
\hline N o da foto & & & & \\
\hline
\end{tabular}




\begin{tabular}{|l|l|l|l|l|}
\hline $\begin{array}{l}\text { Agência produtora } \\
\text { Ano }\end{array}$ & & & & \\
\hline Tamanho da foto & & & & \\
\hline $\begin{array}{l}\text { Forma to da foto e suporte } \\
\text { (rela ção com o texto escrito) }\end{array}$ & & & & \\
\hline Tipo de foto & & & & \\
\hline $\begin{array}{l}\text { Enquadramento I: sentido da foto } \\
\text { (horizontal ou vertical) }\end{array}$ & & & & \\
\hline $\begin{array}{l}\text { Enquadramento II: direção da foto } \\
\text { (esquerda, direita, centro) }\end{array}$ & & & & \\
\hline $\begin{array}{l}\text { Enquadramento III: distribuição de } \\
\text { planos }\end{array}$ & & & & \\
\hline $\begin{array}{l}\text { Enquadramento IV: objeto central, } \\
\text { arranjo e equilíbrio }\end{array}$ & & & & \\
\hline N itidez I: foco & & & & \\
\hline $\begin{array}{l}\text { N itidez II: impressão visual (definição } \\
\text { de linhas) }\end{array}$ & & & & \\
\hline N itidez III: iluminação & & & & \\
\hline Produtor: a mador ou profissional & & & & \\
\hline No da foto & & & & \\
\hline
\end{tabular}

Cada um dos campos das duas fichas deverá ser preenchido por itens presentes nas fotografias, concebidos como unidades culturais. 0 conceito de unidade cultural, sob o ângulo semiótico, é assim a presentado por Umberto Eco:

uma unidade é simplesmente toda e qua lquer coisa culturalmente definida e individuada como entidade. Pode ser pessoa, lugar, coisa sentimento, estado de coisas, pressentimento, fantasia, alucinação, esperança ou idéia [...] uma unidade cultural pode ser definida semioticamente como unidade semântica inserida num sistema. [...] Reconhecer a presença dessas unidades culturais (que são, portanto, os significados que o código faz corresponder ao sistema de significantes) significa compreender a linguagem como fenômeno socia ${ }^{15}$.

Feito isso, tais unidades cultura is serã o realocadas em categorias espaciais, estabelecidas para a estruturação final da análise, a saber: 
Espaço fotográfico: compreende o recorte espacial processado pela fotografia, incluindo a natureza desse espaço, como se organiza, que tipo de controle pode ser exercido na sua composição e a quem está vinculado fotóg rafo a mador ou profissional -, bem como os recursos técnicos colocados à sua disposição. N essa categoria estão sendo considerados as informa ções relativa sà história da técnica fo to gráfica e os itens contidos no plano da exp ressã o - tamanho, enquadramento, nitidez e produtor - que consubstanciam a forma da expressão fo to gráfica.

Para a composição do espaço fotográfico recuperam-se as unidades cultura is relaciona das à elaboração da lingua gem fo to gráfica, buscando-se criar um padrão descritivo que evidencie as opções efetivamente realizadas. Para cada item do plano da forma da expressão são definidas as variações básicas. Por exemplo:

Tamanho: numa série de fotografias o tamanho variará em função do tipo de câmera e do suporte. Assim, as fotos de família dos anos 1960, feitas com uma Kodak instamatic seguiam um padrão dado pela câmera e pela película utilizadas. Já nas revistas ilustradas, o papel desempenhado pelo editor das matérias fazia com que as fotografias variassem de tamanho de acordo com a sua importância nos termos da ênfase da notícia. Era comum que fotos de impacto para a opinião pública tivessem tamanho grande, geralmente uma página dupla. 0 fundamental é a valiar a variação do ta ma nho na série (composta por fo to grafias privadas, da imprensa, associadas ao poder público, de empresas, etc.)

Formato e suporte: da mesma forma que o item tamanho, o forma to também varia em função da câmera utilizada, do suporte de veiculação e das finalidades sociais da fotografia. Uma fotografia no modelo carte de visite do século XIX tinha o seu forma to e tamanho padronizados (retangular $6 \times 9 \mathrm{~cm}$ ) pela câmera inventada pelo fotógrafo francês Eugene Disdéri, em 1864 , para a produção de retratos. No entanto, o fotógrafo poderia usar o efeito flou, envolvendo a imagem do retratado com nuvens, ou ainda usar uma janela oval dentro da imagem. N esse caso, como no anterior, a definição da variação se fará em função da natureza da série.

Tipo de foto: nesse item define-se se a foto é instantânea ou posada. A sua definição se faz em função da presença ou não de uma encenação, ou ainda, da disponibilidade técnica para a realização da fo to instantânea. Portanto, somente no final do século XIX, ocorreram as condições técnicas para o surg imento de fotos instantâneas.

Enquadramento I - sentido da foto: define-se em torno dos eixos vertical e horizontal, que estão relacionados à posição do visor da câmera na composição da foto. As variações de sentido se associam às opções de estilo, por exemplo, os fotógrafos paisagistas do século XIX buscavam por meio da utilização de chapas de grande forma to a elaboração de um arranjo fotográfico que dialogasse com as pinturas a óleo, impondo o sentido horizontal, como predominante. 
Enquadramento II - direção da foto: estabelece o caminho proposto para a leitura da fotografia. Em geral, os estudos sobre visua lidade a firmam que o observador inicia o percurso do seu olhar pela imagem da direita para a esquerda de cima para baixo, numa trajetória em "S". N o entanto, as imagens fo tog ráficas inscrevem, pela disposição dos elementos no a rranjo fotográfico, um percurso a ser seguido pelo olhar que nem sempre segue esse padrão geral. 0 que de fato determina o caminho a servarrido pelo olhar é a composição na foto e o papel que desempenha na série. Por exemplo, as fotografias de família, que povoavam os álbuns de retra tos oitocentista, tinham como padrão a direção central, evidente para enfatizar o tema retratado - o indivíduo. Já nas revistas ilustradas da primeira metade do século XX, a va riação entre as três direções de forma relativamente equilibrada supõe o movimento das páginas a folhear-se uma revista.

Enquadramento III - distribuição de planos: a colocação do maior número de planos dentro do enquadramento diz respeito a duas condições, uma de caráter técnico, a profundidade de campo dada pelo controle do diafragma da câmera, e outra associada aos objetivos da mensagem fotográfica, pois quanto mais planos o fotógrafo conseguisse colocar no foco, mais informações incluiria na fotografia. Assim, as fotografias de Augusto $M$ alta quando do registro das obras de Pereira Passos, na cidade do Rio de Janeiro, no início do século XX, primavam pela capacidade de dispor na sua composição a té três planos. Isso porque, o fundamental dessa fotografia era registrar a ação do poder público na modernização da cidade, quanto mais elementos informassem tal ação, melhor seria.

Enquadramento IV - objeto central, a rranjo e equilíbrio: na verdade esse último item do enquadramento poderia ser condensado na noção de composição fo to gráfica, estando assim estreitamente ligado à s condições de nitidez. Toda a fotografia tem um objeto central, que qualifica a mensagem fotográfica, variando de acordo com a agência e tempo histórico de produção da imagem. N o entanto, sempre esse objeto deve ser apresentado a partir da relação que estabelece com o ento rno e/ ou fundo. Dependendo dos objetivos na construção da composição, em to rno do objeto central, o a rranjo dos elementos da foto pode ser linear ou espalhado, concentrar-se na parte superior ou inferior ou a inda equilibrar a sua distribuição pelo marco da foto. Um exemplo, a célebre foto de Erno Schneider, vencedora do Prêmio Esso em 1962, tirada de Jânio $\mathrm{Q}$ uadro com os pés invertidos, é uma forma clara de mostrar que a composição definida em torno do objeto central elabora uma mensagem que se inscreve como signo da situação histórica.

$\mathrm{N}$ itidez - foco, impressão visual e iluminação: a ssocia-se às condições de inteligibilidade visual. 0 fato de só o objeto central ou de todos os planos estarem no foco, enquanto os dema is elementos estão desfocados, produz uma diferença visual significativa, interferindo na recepção da mensagem visual. Da mesma forma, a impressão visual, definida por um contraste maior ou menor, habilita a distinção entre os elementos da foto. Por fim a ilumina ção, com ma is 
ou menos sombra, caracteriza o tipo de relação entre os elementos na composição fotográfica. É possível, de maneira esquemática, estabelecer algumas va riações básicas em torno do item nitidez, sendo assim, temos: fora de foco, objeto central no foco, tudo no foco (quando todos os planos estão dentro do foco); impressão visual: linhas bem definidas (quando o contraste é forte), linhas definidas (quando o contraste é suficiente), linhas mal definidas (quando 0 contraste é fraco, a foto esmaecida ou ainda fora de foco); iluminação: clara com sombras (quando a fo to define bem os elementos, mas apresenta sombra como efeito estilístico), cla ra sem so mbras (fotos com definição clara de elementos sem sombra alguma) e escura (apresenta dificuldade de visualização por erro técnico).

$\mathrm{N}$ as coleções familiares, em que algum membro da família é 0 responsável pela produção das fotos, é muito comum guardar fotos fora de foco com o mesmo cuidado que se guardam as outras de qualidade técnica superior. $\mathrm{N}$ esse caso, o referente, que não pode ser claramente visualizado, mantém-se como objeto central da foto desejada, guardada na imaginação pela memória da experiência vivida.

A questão da interpretação histórica das opções técnicas e estilísticas definidoras do espaço fotográfico insere-se na discussão sobre o conceito de intertextualidade, exposto anteriormente. $\mathrm{N}$ esse sentido, só se pode compreender determinadas escolhas visuais no marco da sua historicidade e pela relação que as fotografias estabelecem com outros textos culturais.

o espaço geográfico compreende o espaço físico representado na fotografia, caracterizado pelos lugares fotografados e a trajetória de mudanças a o longo do período que a série cobre. Tal espaço não é homogêneo, mas marca do por oposições como campo/ cidade, fundo artificial/ natural, espaço interno/ externo, público/ privado, etc. $\mathrm{N}$ essas ca teg orias estão incluídos os seguintes itens: a no, local, a tributos da paisagem, objetos, tamanho, enquadramento, nitidez e produtor.

Ao espaço do objeto estão integrados todos os objetos fotografados to mados como a tributos da imagem fotográfica. A na lisa-se, nessa categoria, a lógica existente na representação dos objetos, sua relação com a experiência vivida e com o espaço construído. Assim, estabeleceu-se uma tipologia básica constituída por três elementos: objetos interiores, exteriores e pessoais. $\mathrm{N} \mathrm{a}$ composição do espaço do objeto estão incluídos os itens tema, objetos, a tributo das pessoas, atributo da paisagem, tamanho e enquadramento.

0 espaço da figuração é composto pelas pessoas e anima is retra tados, pela natureza do espaço (feminino/ masculino, infantil/ adulto) e pela hierarquia das figuras e seus atributos, incluindo-se aí o gesto. Tal categoria é formada pelos itens pessoas, a tributos da figuração, tamanho, enquadramento e nitidez.

N o espaço da vivência (ou evento) estão circunscritas as a tividades, vivências e eventos que se tornam objeto do ato fotográfico. Esse espaço é concebido como uma categoria sintética, por incluir todos os espaços anteriores e por ser estruturado a partir de todas as unidades cultura is. É a própria síntese do a to fotográfico, superando em muito o tema, à medida que, a o incorporar a idéia de performance, ressalta a importância do movimento, mesmo em imagens 
16. LEITE, 1993, p. 19.

17. DUBOIS, p. 55. fixas. 0 u, para se utilizar a terminologia de C artier-Bresson, trata-se do movimento de quem posa ou é flagrado por um instantâneo e do movimento de quem monta a cena ou capta o "momento decisivo".

Pelo exposto, fica evidente que a mesma unidade cultural pode estar presente em diferentes campos espacia is e que tais campos não são estanques. $\mathrm{N}$ a verdade, eles possuem interseções, à medida que representam reconstruções de realidades sociais. Daí os campos espaciais permitirem o restabelecimento dos códigos de representação social de comportamento, no seu marco de historicidade.

Vários autores - dentre os quais o já cita do Umberto Eco, a artista plástica e teórica da arte Fayga 0 stroyer e a historiadora M íriam M oreira Leite, que de longa data reflete sobre a utilização da fotografia como fonte histórica são unânimes na escolha da noção de espaço como chave de leitura das mensagens visua is por causa da natureza desse tipo de texto. Vale a referência ao trabalho de M íriam Moreira Leite pela dimensão histórica que tal escolha assume:

Chegou-se a conclusão de que a noção de espaço é a que domina as imagens fotográficas explícitas. $N$ ão apenas as duas dimensões em que a imagem representa as três dimensões do que comunica. Mas toda captação da mensagem manifesta se dá através de arranjos espacia is. A fotografia é uma redução, um arranjo cultural e ideológico do espaço geográfico, num determinado instante ${ }^{16}$.

Finalmente, a própria experiência vem demonstrando que, a cada novo tipo de fotografia e objeto a ser estudado a partir da imagem fotográfica, o pesquisador vê-se obrigado a a tualizar o método de análise e adequá-lo à sua matéria significante, guardando os imperativos metodológicos ap resentados. $\mathrm{N}$ esse sentido, é sempre importante lembrar que toda a metodologia, longe de ser um receituário estrito, a proxima-se ma is de uma receita de bolo, na qual, cada mestre-cuca adiciona um ingrediente a seu gosto.

$\mathrm{N}$ unca ficamos passivos diante de uma fotografia: ela incita nossa imaginação, nos faz pensar sobre o passado a partir do dado de materialidade que persiste na imagem. Um indício, um fantasma, talvez uma ilusão que, em certo momento da história, deixou sua marca registrada, numa superfície sensível, da mesma forma que as marcas do sol no corpo bronzeado, como lembrou Dubois ${ }^{17}$. N um determinado momento 0 sol existiu sobre aquela pele, num determinado momento aquilo existiu diante da objetiva fotográfica, diante do olhar do fotógrafo, e isto é impossível negar.

Discute-se a possibilidade de mentir da imagem fotográfica. A revolução digital, provocada pelos avanços da informática, torna isso cada vez ma is presente, permitindo que a té os mortos ressurja m para tomar mais um chope tal como a publicidade já mostrou. $N$ ão importa se a imagem mente; 0 importante é saber por que e como mentiu. 0 desenvolvimento dos recursos tecnológicos demandará do historiador uma nova crítica que envolva o conhecimento das tecnologias feitas para mentir. 
Toda a imagem é histórica. 0 marco de sua produção e o momento

\section{PANOFSKY, 1991.}

19. Um estudo mais sistemático sobre as revistas ilustradas do período, considerando os elementos propriamente fotográficos como gêneros, articulações narrativas, relação texto/imagem e 0 impacto da modernização técnica no uso da linguagem fotojornalística, está sendo organizado com resultado de minhas pesquisas recentes.

20. BARTHES, 1989, p. 208.

Segunda parte

Fotografia de imprensa e o gosto burguês no Rio de Janeiro, na primeira metade do século XX

Vivemos em um mundo repleto de imagens, consta tação que sobrevive no senso comum dos habitantes das cidades deste novo milênio. No entanto, entre o sujeito que olha e a imagem que elabora existe muitos mais do que os olhos podem ver.

É interessante notar que o processo de naturalização e homogeneização das representações por elas eng endradas se faz, par a par, à instituição da ordem burguesa, movimento pelo qual a burguesia transforma a realidade do mundo em imagem do mund $0^{20}$. Portanto, o que aparenta natura lidade é, em suma, o resultado desse processo de investimento de sentido.

A produção de sentido envolve as sociedades históricas desde que 0 primeiro homem manifestou-se por meio de gestos e desenhos nas paredes das ca vernas. A escolha da expressão correta para produzir um determina do conteúdo é resultado de uma experiência histórica de julgar, escolher e interpretar. Existe sempre um conjunto de escolhas possíveis, a partir do qual, uma escolha é feita. Tal conjunto pode, com certeza, ser denominado de cultura. 
Ao longo dos primeiros 50 a nos do século XX, a capital federal passou por intervenções cirúrgicas na sua forma urbana, resultado de uma política que visava a moldar a metrópole tropical à imagem e semelhança das cidades temperadas. $\mathrm{N}$ esse sentido, bulevares substituíram vielas, cafés e confeitarias os freges e quiosques, e o pacato cidadão deu lugar a o dandy ou ao smart, todas as instâncias do viver em cidade foram sendo adequadas a um novo padrão de comportamento. N esse processo, as revista s ilustradas de críticas de costumes, publicadas na cidade desde o início do século, tiveram um papel fundamental.

Janelas que se abrem para o mundo por meio dos clichês fotográficos, os periódicos ilustra dos possibilitaram a divulgação e assimilação rápida de imagens de pessoas, objetos, lugares e eventos contribuindo, de forma decisiva, para a criação desse novo padrão de sociabilidade.

0 presente trabalho objetiva levantar a discussão do papel da imagem fotográfica, veiculada pela imprensa ilustrada, na conformação do gosto na sociedade carioca, da primeira metade do século XX. Um gosto que resulta no julgamento de comportamentos, aceitando uns e rejeitando outros, considerados 0 reverso da imagem.

A construção histórica do gosto, por meio da imagem técnica, é uma temática relevante principalmente na sociedade contemporânea, dominada pela relação mediatizada que se tem entre a realidade e sua representa ção e vivência. Discutir a dimensão histórica desse processo implica desnaturalizá-lo, retirando-0 do senso comum a a nalisá-lo de forma crítica.

$\mathrm{N}$ a mira do próprio olhar: as revistas ilustradas no Rio de Janeiro na primeira metade do século XX

Careta, Fon-Fon, 0 Cruzeiro, Revista da Semana, Kosmos, M a lho, Avenida, Ilustração Brasileira, Rua do O uvidor, Vida Doméstica, Selecta, Eu Sei Tudo, Para Todos, Vamos Ler, Scena Muda, C inearte, Beira Mar, entre outras, compuseram o perfil de uma época em que as imagens fotográficas tinham nas revistas ilustradas o seu principal veículo de divulgação.

Um veículo que, por meio de uma composição editorial adaptada ao seu próprio tempo e às tendências internacionais, criavam modas e impunham comportamentos, assumindo a estética burguesa como a forma fiel do mundo que representavam.

Janelas que se abriam para o mundo retratado na foto, ta is revistas contribuíram, em grande medida, para a generalização do mito da verdade fotográfica, na medida em que, por meio de suas crônicas e notas sociais, impunham valores, normas e criavam realidades, num processo que transforma ria a cidade em cenário e as frações da classe dominante, associadas às agências do Estado e às atividades urbanas, tais como setor de serviços, comércio de exportação e capital financeiro, em seus atores principais. Assim, foram importantes instrumentos, desse grupo social, no empenho de naturalizar suas 
representações pela imposição de uma determinada forma de ver e reproduzir 0 mundo, sobre todas as outras possíveis.

Consumidas por quem era o seu conteúdo principal, ta is revistas auxiliaram também a coesão interna do grupo em ascensão social. Com efeito, veicula vam comportamentos tidos como necessários para se tornar um bom cidadão, a tua ndo como modelos a serem copiados e exemplos a serem seguidos.

$\mathrm{N}$ a primeira metade do século XX, as revistas ilustradas passaram por importantes transforma ções, muito mais de forma do que de conteúdo. Adaptandose às mudanças políticas, às influências internacionais e ao mercado consumidor que, a o longo desse período, cresce e se diversifica, o leitor da Fon-Fon ou da Careta, de 1908, por exemplo, poderia ser o mesmo a té 1950, porém com certeza dividiria as suas páginas com seus filhos e netos, frutos de um outro tempo, mas pertencentes à mesma classe social. Daí a manutenção de determinados conteúdos de classe que, simplesmente ao longo do tempo, adaptaram-se às novas tendências. Entre 0 dandy e o self-made-man existe uma diferença de forma, mas a substância, para a sociedade carioca, é a mesma.

Em linhas gerais, esse longo período da história das publicações ilustradas de críticas de costumes, que circunscreve a primeira metade do século XX, pode ser dividido em dois subperíodos delimitados por transforma ções de ordem técnica que influenciaram a forma de apresentação dessas revistas.

0 primeiro subperíodo se inicia em 1900 com a introdução de fotografias na Revista da Semana, o único periódico ilustrado com fotos a té então, e se prolonga a té 1928 , quando foi lançada a revista 0 Cruzeiro, um marco na história do jornalismo brasileiro, tanto por introduzir uma linha editorial de influência marcadamente norte-americana quanto pelo aumento significativo no uso de fotos.

$\mathrm{N}$ esse primeiro momento, o tom das publicações variava do crítico e cômico ao refinado e artístico, circunscrevendo o universo mental da elite carioca em todas as suas possibilidades. A tendência crítica e cômica pode ser exemplificada nos editoria is de lançamento das revistas Fon-Fon e Careta. A Fon-Fon se lançava como um "semanário alegre, político, crítico e esfuziante, noticiário avariado, telegrafia sem arame e crônica epidêmica" cujo único objetivo era

fazer rir, alegrar a tua boa alma carinhosa [...] com o comentário leve das coisas da a tualidade [...]. Para os graves problemas da vida, para a mascarada política, para a sisudez conselheiral das finanças e da intrincada complicação dos princípios sociais, cá temos a resposta própria: a perta-se a sirene... FO N FO N ! ${ }^{21}$.

A revista Careta, por sua vez, seguia o mesmo tom de pilhéria, propondo em seu editorial "um programa vasto e sedutor" para o público "apreciador das sessões galantes do jornalismo smart" ${ }^{22}$. Dentro dessa mesma linha editorial, situa vam-se a Revista da Semana e o Malho, esta última foi lançada em 1902 e especializou-se em crítica política e caricaturas. A tendência mais refinada e artística teve como representantes a llustração Brasileira e a Kosmos. Em 1904 surgiu o primeiro número da Kosmos, uma revista nos moldes 
23. NOSSO SÉCULO 1980, v. I, p. 220. modernos dos semanários internacionais, a presentando, portanto, uma publicação bem cuidada de acabamento primoroso. À época de seu lançamento, a revista Kosmos foi descrita da seguinte maneira: "um primoroso álbum de nossas belezas e primores artísticos, propagando o seu conhecimento a outros pontos do país e do estrangeiro" ${ }^{23}$. N o seu conteúdo constavam manifestações artísticas e literárias e crônicas e reportagens sobre eventos sociais da elite endinheirada da cidade do Rio de Janeiro. Colaboravam nessa revista: A rthur Azevedo, Gonzaga Duque, Capistrano de Abreu e Euclides da C unha.

0 segundo subperíodo se inicia com o lançamento da revista 0 Cruzeiro e se prolonga, em termos de linha editorial, a té a década de 1960, com a introdução, entre outras modificações, da cor nas fotos de revista.

Essa nova etapa das publicações ilustradas diferencia-se da anterior tanto pela introdução de novas técnicas de impressão, como a rotogravura, quanto por uma redefinição no perfil do mercado editorial, ávido por informações atualizadas. Tais fatores foram definitivos para a mudança no padrão estético e informativo das revistas ilustradas. Enquanto o primeiro momento foi fortemente marcado pela presença de textos ficcionais, crônicas e fotografias pequenas e independentes do texto escrito, o segundo enfatiza a notícia, a interpretação dos fatos nacionais e internacionais e as fotografias em grande formato.

É importante enfatizar a diferença entre esses dois subperíodos como forma de caracterizar as mudanças inscritas na própria transformação da audiência das revistas, dentre as quais se pode destacar: a ampliação dos estratos médios da sociedade carioca, o crescimento urbano, a valorização de padrões comporta menta is associados aos meios de comunicação, etc.

A revista 0 Cruzeiro foi lançada em $10 / 11 / 1928$, com uma tiragem inicial de 50.000 exemplares, cifra bastante significativa para a época. Em seu editorial de lançamento, evidenciou-se o perfil moderno e inovador que $0 \mathrm{~s}$ Diários Associados, empresa pertencente a Assis $C$ hateaubriand e responsável pela publicação de 0 Cruzeiro, 0 Jornal e o Diário da N oite, queriam traçar para si mesmos:

Depomos nas mãos do leitor a mais moderna revista brasileira. $\mathrm{N}$ ossas irmã s mais velhas nasceram por entre as demolições do Rio Colonial, a través dos escombros a civilização traçou a reta da avenida Rio Branco: uma reta entre o passado e o futuro. O C RUZEIRO encontrará ao nascer o arranha-céu, a radiotelephonia e o correio aéreo. 0 esboço de um mundo novo no novo mundo [...]. A revista é um compêndio da vida [...] revela a sua expressão educativa e estética, por isso a imagem é um elemento preponderante. Uma revista deve ser como o espelho leal onde se reflete a vida, seus aspectos edificantes, a traentes e instrutivos (0 Cruzeiro, 10/11/ 1928).

$\mathrm{N}$ esse contexto, ao mesmo tempo em que a revista 0 Cruzeiro se inseria no conjunto das chamadas publicações "frívolas", advogava para si o direito quase missionário de ser o espelho fiel da vida. A imprensa segundo a concepção dessa revista ficaria encarregada da nobre missão de, no caso dos jornais, julgar e, no das revistas, depurar os fatos da vida para que o leitor se educasse de forma correta. 
Essa postura tem como premissa básica a idéia de que o que está escrito é a própria verdade. Tal concordância seria reforçada pela utilização maciça de imagens. Isso porque a imagem, diferentemente do texto escrito, chega de forma ma is direta e objetiva à compreensão, com menos espaço para dúvidas, pois o observador confia nas imagens técnicas tanto quanto nos seus próprios olhos.

Com o intuito de reafirmar o papel predominante da imagem sobre 0 texto, a empresa dos Diários Associados investiria, três a nos depois do la nça mento da revista, na modernização dos equipamentos de impressão, buscando uma melhoria na qualidade da imagem fotográfica. Rapidamente as páginas de 0 C ruzeiro ganharam cor, a princípio a penas em ilustrações e caricaturas e, bem mais tarde, em fotografias.

Em sua primeira fase editorial, que se prolongaria até o final da década de 1930, 0 Cruzeiro, a pesar de em muitos pontos assemelhar-se às outras revistas ilustradas contemporâneas, especialmente à Revista da Semana, a presentou um cará ter mais cosmopolita, obtido pela utilização dos serviços das a ências de notícias internacionais, a mpliando a ssim o seu universo temático. Um exemplo disso foi o aparecimento de sessões exclusivas como a chamada: Pelas Cinco Partes do M undo.

No entanto, foi a partir da década de 1940 que a revista incorporaria o padrão de qualidade das publicações internacionais, incluindo, desde então, nas suas primeiras páginas, um detalhado expediente, em que se podia constatar a especialização de seus serviços em vários departamentos, nos moldes das famosa s revistas Life, Look, Paris Match, entre outras. Por essa época, 0 C ruzeiro já contava com uma tiragem de 120.000 exemplares.

Dentre os repórteres que faziam parte do quadro regular da revista constavam: David N asser, Edmar M orel, Rocha Pita, N elly Dutra, etc. Como colaboradores eventuais: José lins do Rego, Rachel de Q ueiroz e M illôr Ferna ndes. $C$ abe ressaltar que foi 0 C ruzeiro a primeira publicação a conceder 0 crédito das fotografias publicadas, contando inclusive com um departamento e equipe de fotografia que reunia profissionais como: Jean Manzon, Edgar Medina, Salomão Scliar, Lutero Avila, Peter Scheir, Flávio Damm, José M edeiros entre outros. Todos estavam enca rregados de introduzir uma linguagem fo to gráfica: 0 fo to jorna lismo.

Essa nova linguagem era imbuída de um caráter didático e de um controle rígido da correlação texto/ imagem por parte da equipe editorial. 0 fa to é literalmente construído, dessa forma as fotografias deixaram de ser apenas dispostas nas pá ginas das revistas para serem, com diferentes ta manhos e formas, deliberadamente arranjadas rompendo com o esquema ilustrativo tradicional.

Com ta is mudanças, a revista 0 Cruzeiro promoveria uma reformulaçã 0 geral no padrão das publicações ilustradas, que tiveram de reordenar toda sua linha editorial para concorrer com o novo padrão estético imposto. Algumas publicações que tradicionalmente tinham uma boa entrada no mercado, como Careta, Fon-Fon e Revista da Semana, conseguiram se reformular e sobreviver. 
24. Os anos-chave foram definidos a partir de uma análise rigorosa da totalidade dos anos publicados. Com o decorrer do tempo, as revistas apre sentaram mudanças na linha editorial como diminuição do texto escrito em relação à foto, amplia ção do número de fotos, mudança na identidade visual, anúncio de inovações técnicas pelo editor, trocas na equipe de colaboradores, etc. Enfim modificações ligadas ao próprio veículo. Porém foram considerados também anos importantes aqueles em que ocorre ram marcos cruciais re lacionados à história da cidade/país e do mundo, tais como as grandes guerras mundiais, exposições nacionais e internacio nais, reformas urbanas, eleições, etc.Via de regra o que vigorou foi um entrecruzamento desses dois critérios.
Ver, ima ginar, criar: os quadros de representação social

da classe dominante nas revistas ilustradas cariocas

Para proceder à recuperação dos quadros das representações socia is de comportamento da burguesia urbana elaborados pela imprensa ilustrada carioca, na primeira metade do século XX, por meio da imagem fotográfica, organizou-se um corpus, ou seja, uma série fotográfica extensa e homogênea. Tal série foi composta por 867 fotografias selecionadas das revistas 0 Cruzeiro e $C$ areta, nos anos-chave em que ocorreram modificações nas suas formas de expressão e conteúdo ${ }^{24}$.

$\mathrm{N}$ esse sentido destacou-se respectivamente $1908,1914,1922$, 1928,1935,1942 e 1949 para a revista Careta e 1928,1934,1943 e 1950 para a revista 0 C ruzeiro. Em cada a no foram escolhidos três números relativos, cada um a uma época do ano: janeiro/ fevereiro, junho/ julho e dezembro, com o intuito de cobrir os principais eventos da cidade, ta is como: festas de fim de ano, carnaval e as aberturas de temporada - verão e inverno. Vale lembrar que essas revistas foram escolhidas pela constância na periodicidade, volume de fotografias, condições de acesso e reprodução das imagens e por serem um exemplo típico de dois momentos das publicações ilustradas, a nteriormente assinalados.

0 segundo passo foi a escolha de um eixo de análise que dominasse o caráter não-verbal da linguagem fotográfica. 0 p tou-se pela avaliação de como a noção de espaço foi codificada na mensagem fotográfica elaborada pelas revistas ilustradas. Tal escolha justifica-se tanto pelo papel determinante que a noção de espaço ocupa nas linguagens visuais, gestuais, etc. quanto nos critérios a partir dos quais o imaginário urbano é construído, tomando-se sempre como referência básica a existência de um topos. Assim, a noção de espaço codifica tanto a expressão da linguagem fotográfica quanto o conteúdo a ela subjacente nos semanários ilustrados da primeira metade do século XX.

Entretanto, cabe ressaltar que essa noção não é homogênea. Tal como foi exposto na primeira parte deste texto, seu desdobramento é balizado pelas unidades culturais que estruturam a mensagem fotográfica e que podem ser organizadas, para efeito de análise, nas seguintes ca tegorias espacia is: espaço fotográfico, geográfico, do objeto, da figuração e da vivência.

Cada uma delas é analisada separadamente; no entanto, na dinâmica de produção de sentido social, entrecruzam-se. Em tal processo, balizam a elaboração dos quadros de representação social, norteadores das formas de ser e agir da burguesia urbana.

As opções estéticas, as formas de consumo, os lugares da cidade que deveriam ser freqüentados, como signo de distinção e pertencimento social, enfim, toda a codificação em torno da noção de "bom gosto" (identificado com o gosto burguês) era estabelecida pelas imagens fotográficas e padrão gráfico das revistas ilustra das. 
A seguir serão avaliadas as categorias espacia is nas fo to grafias de a mbas as publicações - C a reta e 0 C ruzeiro -, buscando-se, com isso, recuperar os comportamentos e os quadros de representação social correspondentes à burguesia urbana ${ }^{25}$ em ascensão.

Flagrantes e instânta neos

A composição do espaço fo to gráfico está intimamente relacionada a o tip o de a parelhag em utiliza da. A má quina fo to gráfica limitará as possibilidades de enquadramento, tamanho, profundidade de campo e nitidez da foto.

As imagens fotográficas das revistas ilustradas passa ram por uma variação de padrão correspondente à própria evolução da técnica fotográfica e do acesso que as redações das revistas tinham a esse progresso tecnológico. Paralelamente a essas variá veis, mais um fator interfere na composição do espaço fotográfico das revistas: a relação da imagem com o texto escrito.

Dessa forma, as variáveis na composição do espaço fo to gráfico foram:

- Tamanho: variou entre pequeno, médio e grande. As fotos pequenas to maram no máximo $1 / 8$ do espaço total da página, as médias, cerca de $1 / 4$ e as grandes, mais de 1/2. A opção por expressar os valores métricos em frações ocorreu pelo fato das fotografias não possuírem um padrão métrico constante como as que integram um álbum de família.

- Formato: variou entre o quadrilátero, que inclui o forma to retangular e o quadrado, e a circunferência, que inclui o forma to oval e circular, bem como outras formas semelhantes, como no caso de foto dentro de letras ou emolduradas.

- Suporte: caracteriza-se pela relação entre o texto escrito e a linguagem fotográfica. 0 s tipos de relação podem ser:

1 a relação: reportagem fotográfica com título, texto e legenda.

2 a relação: reportagem fotográfica com título e legenda.

3 a relação: fotografia a vulsa com título e legenda.

4 a relação: fotografia avulsa somente com título.

0 dado levantado é a existência de parceria entre fotógrafo e repórter, ambos assinando seu trabalho, texto escrito e visual. Esse foi um recurso nas reportagens fotojornalísticas a partir do final da década de 1930, o que estabeleceu uma nova relação entre linguagem escrita e visual.

- Tipo da foto: posada ou instantânea, para se avaliar o grau de natura lidade das fotos e se detectar a existência de comportamentos emergentes.
25. A historiografia brasileira sobre o período estudado não é consensual no que diz respeito à utilização do conceito de classe burguesa para esse período da história do Brasil. Noções como camadas médias urbanas, classes médias, frações dominadas da classe dominante são correlativas à noção de burguesia urbana tal como a utilizamos aqui. A opção pelo conceito de burguesiaurbana ocorreu principalmente em conseqüência do objetivo central do estudo: avaliar como, dentro do contexto de inserção do Brasil na lógica do capitalismo internacional, os costumes e comportamentos no espaço das cidades, notadamente na capital, transformaram-se.Tal transformação tomou como referência os códigos de comportamento dos países do hemisfério norte inicialmente a França e a Inglaterra, e, depois da Segunda Guerra Mundial, os EUA que sem dúvida estavam pautados em valores e normas burgueses. Não cabe aqui discutir a base econômica da classe dominante brasileira do período que era eminentemente agrária, mas, absenteísta por natureza e cosmopolita por verniz. 
- Enquadramento: item que reuniu o sentido, a direção e distribuição dos planos, o objetivo central e o arranjo das fotos coletivas, como forma de avaliar a hierarquização do espaço fotográfico e possíveis seqüências de significados.

- N itidez: inclui o foco, a impressão visual e a iluminação. A a va liação apurada de tais itens, a o longo do tempo, permite recuperar as mudanças estéticas na forma de expressão da fotografia de imprensa, enfatizando-se ou não o mito da verdade fotográfica.

A revista $C$ areta apresentou o seguinte padrão de espaço fo tográfico ao longo dos 50 anos cobertos pela análise:

\begin{tabular}{l|l}
\hline Tamanho & $40 \%$ pequeno; $30 \%$ médio e $30 \%$ grande \\
\hline Formato & $99 \%$ retangular \\
\hline Suporte & $44 \%$ reportagem fo tográfica com título e legenda \\
\hline Tipo & $68 \%$ posado e $32 \%$ instantâneo \\
\hline Enquadramento & $\begin{array}{l}66 \% \text { sentido horizontal; } 57 \% \text { direção central; } 80 \% \text { do is planos } \\
\text { distintos; já no grupo misto como objeto central dispostos } \\
\text { eqüita tivamente em semicírculo ou linha reta qua se nã o há } \\
\text { fotos com pessoas espalhadas }\end{array}$ \\
\hline N itidez & $\begin{array}{l}90 \% \text { linhas definidas, com todos os planos no foco, sem } \\
\text { sombras e com contraste }\end{array}$ \\
\hline
\end{tabular}

maneira:

0 espaço fotográfico da revista 0 Cruzeiro configurou-se da seguinte

\begin{tabular}{|c|c|}
\hline Tamanho & $58 \%$ pequeno; $26 \%$ médio e $14 \%$ grande \\
\hline Forma to & $99 \%$ retangular \\
\hline Suporte & $\begin{array}{l}72 \% \text { reportagem fotográfica com título, texto e legenda, sendo } \\
\text { que cerca de } 50 \% \text { foram realizadas nos moldes do foto- } \\
\text { jornalismo) }\end{array}$ \\
\hline Tipo & $60 \%$ posado e $40 \%$ instantâneo \\
\hline Enquadramento & $\begin{array}{l}76 \% \text { sentido vertical; } 56 \% \text { direção central; dois planos } \\
\text { distintos com objeto central concentrado no primeiro plano } \\
\text { por causa da opção vertical ( } 80 \%) \text {; mulher como objeto } \\
\text { central ( } 27 \%)\end{array}$ \\
\hline $\mathrm{N}$ itidez & $\begin{array}{l}90 \% \text { linhas definidas; } 74 \% \text { objeto central no foco; } 90 \% \\
\text { sem sombras e com contra ste }\end{array}$ \\
\hline
\end{tabular}

Como pode ser constatado pelas tabelas existiam poucas diferenças entre as duas revistas. A Careta apresentava imagens com contornos bem 
definidos, planos distintos, equilíbrio de elementos e homogeneidade de organização. Tais opções reafirmam o pressuposto de que aquilo que era exibido na foto mantinha uma relação direta e objetiva com a própria realidade.

Já a revista 0 Cruzeiro foi mais ousada principalmente na avaliação de cada período em separado, quando se constata a influência de outros tipos de imagem, como o cinema, nas opções estéticas. No conjunto dos anos a nalisados, as imagens caracteriza ram-se pela concentração no plano central, homogeneidade, pouca profundidade, definição de linhas e contornos e pela sexualização do espaço figurativo, com a escolha da mulher como objeto central na maioria das fotos.

N uma análise numérica da incidência homem/ mulher como objeto central nas fotos de 0 Cruzeiro, o padrão encontrado fica evidenciado na tabela abaixo. Com efeito, a tendência geral é para a distribuição equilibrada entre 0 espaço feminino e masculino, já que ambos incidem igualmente no primeiro plano. N o entanto, há de se ressaltar a constante incidência da figura masculina em segundo plano e da feminina em plano central, revelando-se aí uma maior valorização da imagem feminina na composição fotográfica da revista. Tal fa to explica-se tanto pela introdução de sessões especializadas em moda s como pela valorização do corpo feminino, a partir da década de 1940, associada a uma mudança em termos de representações culturais do populare do nacional nos meios de comunicação.

\begin{tabular}{l|ccc}
\hline & $1^{\circ}$ plano & $2^{\circ}$ plano & Plano central \\
\hline Figura masculina & $18 \%$ & $8 \%$ & $17,5 \%$ \\
\hline Figura feminina & $18 \%$ & $6,5 \%$ & $27 \%$ \\
\hline
\end{tabular}

Esse padrão, a o contrário do anterior, expressa uma carga maior de subjetividade própria às expressõ es artísticas, fa to que fo i resulta do principa Imente da existência de um grande número de reportagens fotográficas, nos moldes do fo tojo rna lismo, cujas fo to s eram identificada s e o trabalho do fo tó grafo valorizado na sua dimensão criativa muito mais do que informativa.

Por outro lado, a opção pelo fotojornalismo criou uma ancoragem da imagem para com o texto escrito, sendo essa interpretada a partir das idéias escritas, limitando, assim, a autonomia do texto visual em relação ao escrito. Ao mesmo tempo, o fotojornalismo enfatizava o caráter didático que a imprensa assumiu a partir da década de 1940 .

G eografia da diferença

A cidade e suas avenidas, praias, contorno dos morros ou baía - um espaço próximo e vizinho - compõem uma determinada imagem do Rio de Janeiro que por predominar silencia as demais. 
0 Brasil, com suas regiões e paisagens, cria uma imagem que expõe tanto a face da riqueza e desenvolvimento quanto a do lado pitoresco e exótico de um país tão cheio de diversidade.

0 estrangeiro surge nas páginas ilustradas por meio das cidadescapita is e seus modos de vida peculiares. Com imagens que indicam a a mpliação dos contatos internacionais, o mundo coloca-se, como que por mágica, ao alcance dos olhos. Tudo isso incita a curiosidade e a adoção de modismos e comportamentos emergentes.

0 espaço engendrado pela mensagem fotográfica das revistas ilustradas tem como característica básica a variedade. Entretanto, mesmo dentro dessa variedade, existe uma hierarquia de temas que são associados a determinados espaços.

$\mathrm{N}$ o conjunto, as imagens analisadas nas revistas $C$ a reta e $O$ C ruzeiro indicam um espaço geográfico dividido em três grandes blocos regionais, cuja proporção de incidência na imagem foi a seguinte:

\begin{tabular}{lrr}
\hline Região & Careta & 0 Cruzeiro \\
\hline RJ - zona sul & $36,5 \%$ & $24,5 \%$ \\
\hline RJ - zona norte & $7 \%$ & $1 \%$ \\
\hline RJ - centro & $24 \%$ & $15 \%$ \\
\hline RJ - subúrbios & $1 \%$ & $4 \%$ \\
\hline Estado do RJ & $2 \%$ & $9,5 \%$ \\
\hline Fora do RJ, no Brasil & $10 \%$ & $8 \%$ \\
\hline Fora do Brasil & $15 \%$ & $32 \%$ \\
\hline RJ (não identificada) & $4,5 \%$ & $6 \%$ \\
\hline
\end{tabular}

É importante ressaltar que cada uma dessas regiões manteve uma relação com o eixo principal - a cidade do Rio de Janeiro - ora reforçando-the seu cará ter cosmopolita, ora a tribuindo-lhe determinadas funções que podiam ser turísticas, políticas ou propriamente de palco para o desfile de personagens da classe em ascensão: a burguesia.

$0 \mathrm{~s}$ blocos regionais, por sua vez, foram subdivididos em diferentes lugares (ESPAÇOS), compondo uma paisagem formada por clubes com seus salões luxuosos e áreas externas, estádios de esporte, hotéis, praias, avenidas, ruas, edifícios públicos, escolas, teatros, estúdios, a mbientes domésticos, selvas, etc.

Duas regiões se destacam do conjunto: na revista $C$ areta, a zona sul do Rio de Janeiro e na revista $O$ C ruzeiro, o estrangeiro. Emblemas de um estilo de vida que estava se impondo. Comecemos pela zona sul e sua identificação com o habitus da classe dominante.

Ao reunir os bairros litorâneos loca lizados entre o mar e os morros, a zona sul apresenta-se mais distante do centro de negócios e, até os anos de 
1950 , era fundamentalmente voltada à moradia e ao lazer das camadas ma is ricas da população urbana. Portanto, era uma área onde se podia com facilidade retratar a vida, os hábitos, as maneiras de vestir, os passeios, os eventos, etc. de uma classe que cada vez mais se identificava com os valores e comportamentos da burguesia ocidental.

$\mathrm{N}$ a revista Careta, os lugares de maior incidência nas fotos dessa região são parques, avenidas, ruas, clubes, praias, estádios de futebol de clubes, hotéis e veredas tropica is à beira-mar. Assim, os lugares fotografados compunham uma mensagem que reafirmava a vocação desses espaços para o lazer e a diversã 0 .

Essa tendência era evidenciada nas fotografias de escolas, cujo tema escolhido não era o das salas de aula, mas o das festas de formatura e fim de ano; no mesmo estilo, os prédios públicos, principalmente, o palácio do governo localizado no bairro de Laranjeiras (zona sul), compareciam apenas nas fotos de festividades, geralmente, $\mathrm{N}$ atal, quando se distribuíam presentes a os pobres.

$\mathrm{N}$ a revista $\mathrm{O}$ Cruzeiro, a maioria das fotografias a nalisadas é de localidades estrangeiras, com desta que para a Europa 0 cidental e Hollywood. Da Europa 0 cidental chegavam notícias das guerras e dos grandes fatos que marcaram a história contemporânea da humanidade. Porém, era com Hollywood que o carioca (como eram e toda via são chamados os habitantes da cidade do Rio de Janeiro) se reciclava e assimilava o padrão burguês de comportamento como uma norma de atitude.

Ao longo da década de 1920, os Estados Unidos da América cresceram economicamente, despontando como a terra do dinheiro fácil, de homens vigorosos e da ilusão consumista. Eram assim uma sociedade afluente e moldada sob medida para uma classe dominante e carente de um projeto cultural próprio, tal como a burguesia carioca se apresentava. 0 a utomóvel americano e as fitas de Hollywood exportaram o american way of life.

No caso do Rio de Janeiro, capital federal, a indústria cinema to gráfica, por meio da Companhia Cinematográfica Brasileira, consegue intervir no panorama urbano com a construção da C inelândia. Um espaço, no centro de negócios da cidade, totalmente reformado para abrigar as novas salas de cinema. Ir a o cinema havia se transformado no ato de consumo de um produto: o filme, daí a necessidade de loca is adequados para consumi-lo.

Ingressos caros, mas conforto, higiene e luxo eram oferecidos a todos os freqüentadores, pelos qua tro cinemas inaugurados na C inelândia entre 1925 e 1928. Capitólio, 0 deon, Palácio e G lória, com suas estréias espetaculares, produziram um novo espaço de aparência na geografia da cidade. A revista 0 Cruzeiro lança em 1928, a no da inauguração do último cinema do complexo, uma sessão denominada C inelândia. N ela eram tratadas as "coisas do cinema", uma composição de fotografias e comentários sobre a vida pessoal dos artistas, cenas de filme, a qua lidade da audiência nos cinemas, etc. Tal tend ência alastrouse por outras publicações ilustradas que nos a nos subsequentes ina uguraram sessões exclusivamente sobre Hollywood, sinônimo de cinema, dentre as quais desta cam-se: G aleria dos Artistas da Tela (Fon-Fon); N ovidades de Hollywood 
26. Técnicas do Beijo, reportagem publicada, com fotos de artistas se beijando, pela revista O Cruzeiro, em 1934.

27. Para uma avaliação do processo de internacio nalização da cultura por meio das imagens, ver MAUAD, 2001, p. 134 $146 ; 2002$, p. 52-77.
( $C$ a reta): $C$ ine-revista ( 0 C ruzeiro), etc. A lém disso, existiam ainda as revistas especializadas em cinema como: Selecta; Cinearte e Para Todos.

A imagem proveniente de Hollywood influenciava no tipo de indumentária, nos cortes de cabelo, na maquiagem do rosto, na forma de beijar ${ }^{26}$, bem como na redefinição dos locais de lazer da burguesia carioca e na estruturação de um star-system nacional utilizando-se das artistas do rádio. N os anos de 1940 , a política da boa vizinhança iniciada pelos EUA, para os países da América Latina, redefiniria a estratégia de sedução hollyw oodiana. C armem $M$ iranda e o personagem de W alt Disney, Zé C arioca, tornaram-se ícones a partir dos quais deveríamos nos modelar. Uma imagem imposta redefinidora da nossa própria auto-imagem ${ }^{27}$.

A ênfase dada pela revista 0 Cruzeiro a o espaço estrangeiro explicase por ela ser mais cosmopolita e criada com base no novo padrão empresarial da imprensa moderna. Em compasso com essa tendência, mantinha contato direto com as agências internacionais de notícias Schert de Berlim, ABC de Lisboa e o Consórcio Internacional de Imprensa de Paris, além de ter um correspondente especial em Hollywood.

$\mathrm{N}$ essas imagens, há ausências. 0 Leste Europeu e 00 riente surgem somente como paisagens exóticas. No entanto, a América Latina, os bairros pobres da cidade carioca e do Brasil são apagados da imagem dominante como uma realidade inexistente por serem equiparados à condição de periferia na configuração da geopolítica ocidental burguesa.

A mbas as publicações seguem uma tendência semelhante, salvo as ênfases acima apresentadas. 0 C ruzeiro marca sua diferenciação do conjunto de revistas ilustradas, investindo no aspecto cosmopolita do Rio de Janeiro, capital federal, enquanto a $C$ a reta manteve sua tradição de revista de crítica de costumes, tipicamente carioca, elevando as imagens da zona sul ao padrão ideal de representação.

Assim, enquanto $O$ Cruzeiro opõe a cidade a um outro espaço: Rio X M undo, buscando sua identificação, a $C$ a reta complementa a cidade com esse espaço estranho, criando uma nova identificação: Rio $=M$ undo.

Vale complementar tal avaliação pela dimensão política da cidade, centro de decisões ligadas a gerenciamento dos negócios públicos e privados. A cidade capital surge nas fotografias como referência paradigmática de Brasil. Ao longo de 50 anos de imagem, o Rio passa de Paris dos trópicos, símbolo da modernidade sustentada por uma elite agrária dominante, à metrópole sintetizada nos arranha-céus da Avenida Presidente Vargas, inaugurada em 1945. Em todos esses momentos atualiza sua função de centro de poder, local onde se decide o futuro do país e de onde o Brasil se projeta para o mundo civilizado, representando assim a estratégia das classes dominantes em manter a unidade nacional pela identificação do país com sua capital. 
O s objetos, numa coleção de fotografias de revista, são a tributos da mensagem fotográfica que fornecem a dimensão dos lugares retratados e dos seus eventos.

Para efeito de análise, dividiram-se os objetos retratados em três tipos: objetos pessoais, interiores e exteriores. $\mathrm{N}$ a mensagem fo tográfica transmitida pelas revistas ilustradas, tais objetos foram apresentados tanto como dignos do padrão de vida dominante quanto úteis à realização de determinadas tarefas. Entretanto, em ambos os casos, o objeto investe a imagem de determinados significados próprios do espaço e tempo da representação.

o s objetos pessoais estão associados à representação do indivíduo: seu estilo de vida e sua posição na hierarquia social. o s objetos interiores caracterizam o tipo de paisagem que se está retratando: privada ou pública; muitas vezes, como no caso das cenas de filmes, a transposição de objetos interiores para espaços públicos, como estúdios de cinema, visam a criar, justamente, uma ambiência privada. 0 terceiro tipo é formado pelos objetos exteriores, que caracterizam o meio retratado, podendo também, quando associados às pessoas, indicar o estilo de vida e o padrão social no qual elas se enquadram.

É, especialmente, no âmbito dos objetos que a mensagem fotográfica das revistas ilustradas entra na intimidade do leitor, moldando-the os gostos e educando-the 0 olhar, interferindo tanto na sua representação pessoal quanto na criação de novos códigos de comportamento para uso coletivo. Tal processo ocorre porque esses três tipos de objetos, que fazem parte do cotidiano dos receptores das mensag ens fotog ráficas, ao serem recortados da rea lidade vivida e transpostos para a rea lidade da imagem adquirem uma função-signo de modelo, na qual estão investidos de um poder de persuasão a té então não dimensionado. A combinação de redes de significa do compondo objeto + figuração + vivência adere à representação, indicando formas corretas de se comportar em diferentes ocasiões.

$\mathrm{N}$ o conjunto das fotografias ana lisadas, evidenciou-se um estilo de vida baseado no consumo supérfluo do luxo e da abundância de objetos, marca registrada do novo cidadão urbano. Em $70 \%$ das fotos os objetos estão em segundo plano a tuando como elemento de reconhecimento do ambiente retratado, em geral urbano (66\%) e elegante, tais como: clubes (26\%), ruas e avenidas da moda (24\%) e hotéis (14\%). Em termos de objetos pessoais, em $50 \%$ das fotos analisadas a indumentária escolhida incluiu trajes como gala, passeio completo, esporte fino e esportivo. Tal preocupação pelo traje adequado para a hora certa denota a existência de um código do bem vestir pautado na utilização de objetos pessoa is tanto para a caracterização da situação que se está vivenciando quanto como elemento de distinção social. 
O s donos do olhar: hierarquia de gênero e idade

na representação social da burguesia

Compreendendo o espaço da figuração das revistas ilustradas, delimitado pela mensagem fotográfica, a partir de três oposições básicas: grupo/ indivíduo, homem/ mulher e adulto/ criança, desvenda-se um mundo em que os habitantes possuíam lugares determinados no espaço da representaçã 0 , no qual a imagem feminina estava associada à frivolidade e aos papéis de espectadora e modelo exemplar, e a masculina à ação, inteligência e ao poder. No trabalho de relacionar a figuração ao evento retratado, tal distinção evidencio u-se. 0 s homens fora $m$ rela ciona dos às temática s que incluem os evento $s$ sociais, militares, políticos e esportivos, a lém das curiosidades nacionais e internacionais, item que contém uma grande variedade de temas que poderiam incluir desde os a contecimentos cotidianos da cidade - como desa stres de avião ou a uto móveis, especialidades culinárias dos cozinheiros dos principa is hotéis e clubes da cidade, reportagens sobre recursos naturais, etc. - a té as últimas novidades do século XX.

Por outro lado, a imagem feminina foi associada à vida dos artistas e de pessoas famosas da high society internacional e principalmente à moda, sobre a qual havia uma distinção entre as novidades internaciona is e a sua utilização no âmbito nacional. É justamente por meio da imagem da moda nacional que a especialização entre o espaço feminino e masculino evidenciase de forma mais clara, posto que tal temática está representada nas fotografias do Jockey Club, onde as mulheres são retratadas como o público elegante, destacando-se a sua indumentária bem cuidada e o seu estilo elegante. Q uando a figura masculina está incluída nesse âmbito, aparece em segundo plano e em pequeno número. Assim, em tais representações, o espaço masculino associa-se ao esporte e à ação e o feminino à moda e ao papel de assistente.

$\mathrm{N}$ o entanto, foi também no espaço feminino que se incluíram imagens das condições de vida das classes populares, veiculando uma representação dicotômica da sociedade que vem a confirmar os papéis socialmente impostos. A mulher das classes populares é fotografada, via de regra, trabalhando em serviços braçais, como lavar roupa, cozinhar, cuidar de criança, etc. ou em situações de dificuldade e precariedade. A ela são associadas roupas simples; e a sua casa, localizada nos subúrbios desassistidos pelas autoridades, poucos objetos interiores.

$\mathrm{N}$ esse sentido, o espaço feminino para as classes populares é um espaço periférico, que acaba por confundir-se ao coletivo, não recebendo com isso a mesma valorização das mulheres da classe dominante, que surgiam na imagem sempre com boa aparência, em lugares exclusivos e protagonizando situações de lazer ou de romance.

$\mathrm{N}$ a representação criada pela imagem fotográfica, o universo infantil é um simulacro do adulto, no qual todas as potencialidades necessárias para 
formar um cidadão realiza do são a presentadas como condição na tura l e inerente ao grupo social do qual provém.

Em $10 \%$ das fotos a nalisadas, as crianças a parecem sozinhas, em $14 \%$ estão acompanhadas de adultos, e o restante são fotos exclusivamente de adultos. Diante de tal proporção, investiu-se na descoberta dos temas e do tipo de indumentária associados às crianças, para assim dimensionar-se qua is eram as representações sociais que estavam atreladas ao universo infantil.

Basicamente, os eventos sociais, os banhos de mar e os passeios foram os temas que obtiveram a maior incidência de crianças sem a companhia de adultos (21\%). N esse caso, os eventos sociais são formados por festas de encerramento do ano letivo e bailes infantis em ocasiões especiais - o exemplo desse tipo de evento são as fotos da Exposição Internacional de 1922, que contou com o equivalente infantil para o baile comemorativo do centenário da Independência.

A companhada de adultos, as crianças são retratadas nos eventos sociais, militares, políticos, esportivos e nos passeios e banhos de mar (18\%). Dessa vez os eventos sociais, temática de maior incidência (7\%), compõem-se por festas de caridade com a presença de menores carentes.

Com efeito, mesmo quando as crianças são retratada sindependentemente dos adultos, mantêm-se a eles atreladas por meio da temática - geralmente equivalentes infantis para eventos adultos - ou de alguma relação estabelecida, no caso da ação caridosa a marca dessa dependência fica evidenciada.

$\mathrm{N}$ o espaço infantil, a sociedade reaparece segmentada em dois grupos sociais distintos: um que, socia Imente despossuído, depende do universo adulto por meio da caridade e outro que compartilha da fruição dos lugares exclusivos e do consumo dos signos de luxo e riqueza, preparando-se para assumir os papeis já estabelecidos na dinâmica social. A própria indumentária reafirma a existência de tais papéis, tendo em vista que, do conjunto de fotos de crianças acompanhadas ou não de adultos, cerca de $36 \%$ estã o fantasiadas, $18 \%$ trajam passeio completo e $16,5 \%$, esportivo. De acordo com tal proporçã 0 , é a fantasia a escolha principal para compor o espaço infantil, dentre as qua is se destacam as de príncipes, nobres, milita res, esportistas, bailarinas, etc. Imagens que associam as crianças a representações sociais tipicamente adultas e de universo determinado.

Distinção social e vivência de classe na sociedade carioca da primeira metade do século XX

As representações sociais de comportamento engendradas pela imagem fotográfica das revistas ilustradas criaram uma cidade onde os espaços são redimensionados para atividades às qua is não foram programados, em função de uma vivência de classe. Dessa forma, o lazer é associado a o trabalho 
no exercício do poder à medida que os grandes negócios empresariais ou as importantes questões nacionais eram resolvidos em banquetes e festas.

0 s espaços adquiriam uma nova dignidade por terem sido fotografados como a mbientes para eventos exclusivos ou simplesmente porque neles se deixaram fo tografar pessoas ostentando objetos que caracterizavam um determinado estilo de vida associado ao luxo e à exclusividade.

Assim a coesão de classe e a construção de uma capital cosmopolita e moderna, plenamente preenchida por valores burgueses, processa-se tanto pela vivência e pelo consumo de um mesmo universo de signos quanto pela produção de uma imagem onde o locus social aparece como dado inerente a própria História.

Careta, 2/ 1/ 1915, 2/ 2/ 1932.

Defini-se desde os primeiros números da revista a especialização dos espaços da cidade. 0 espaço dos gabinetes e instituições governa menta is é estabelecido como eminentemente masculino assim como o da atividade esportiva. Enquanto na praia, espaço da sociabilidade familiar, a mistura de gênero era constante.

A caridade é uma experiência social reservada às mulheres nos poucos momentos em que a sua presença nos espaços do poder é evidenciada. 0 estabelecimento das competências profissionais se define também a partir do critério de gênero. As representações do feminino assumem a polifonia da sociedade urbana e industrial com a mulher profissional, glamorosa e participante, ratificando assim a sua condição de classe.

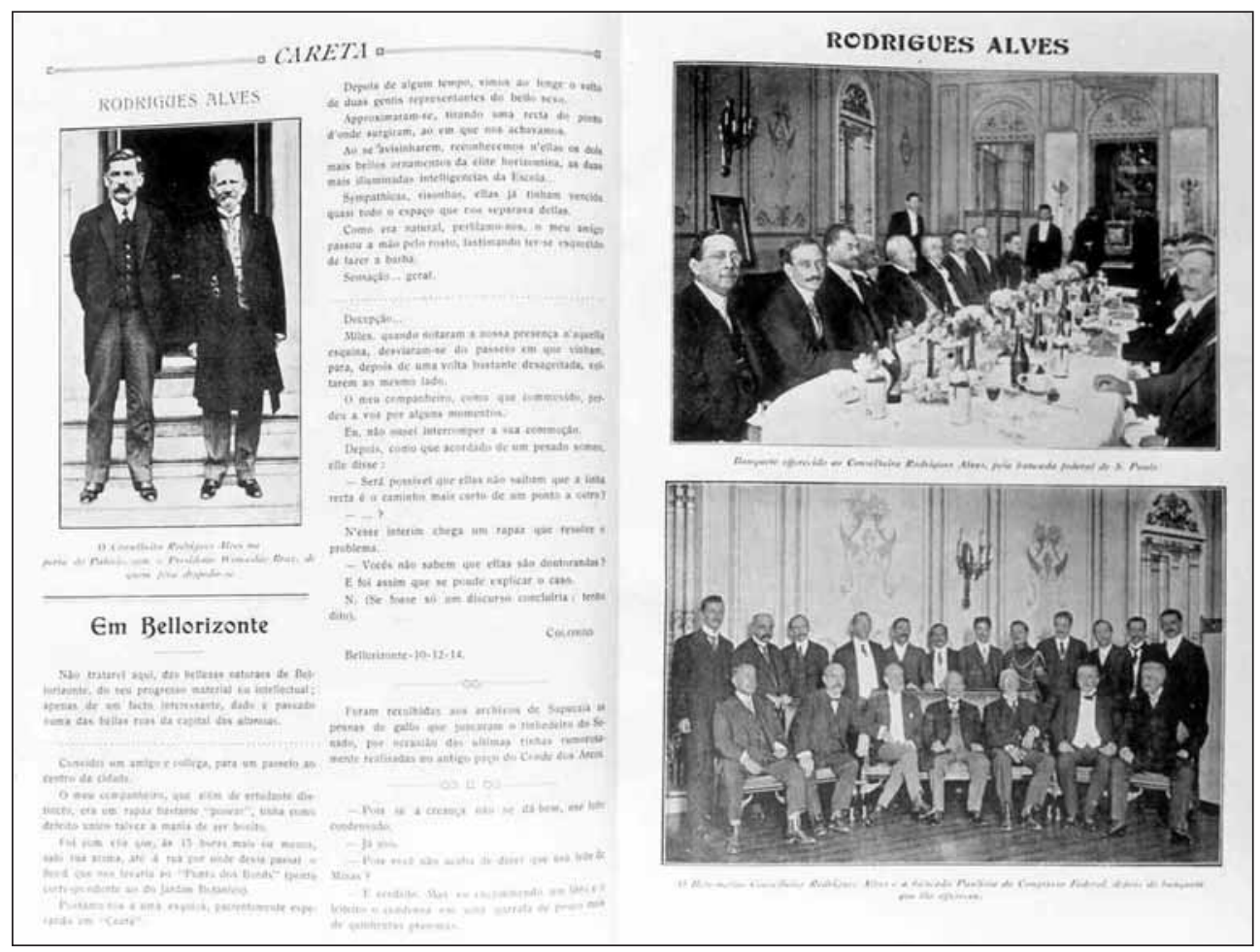



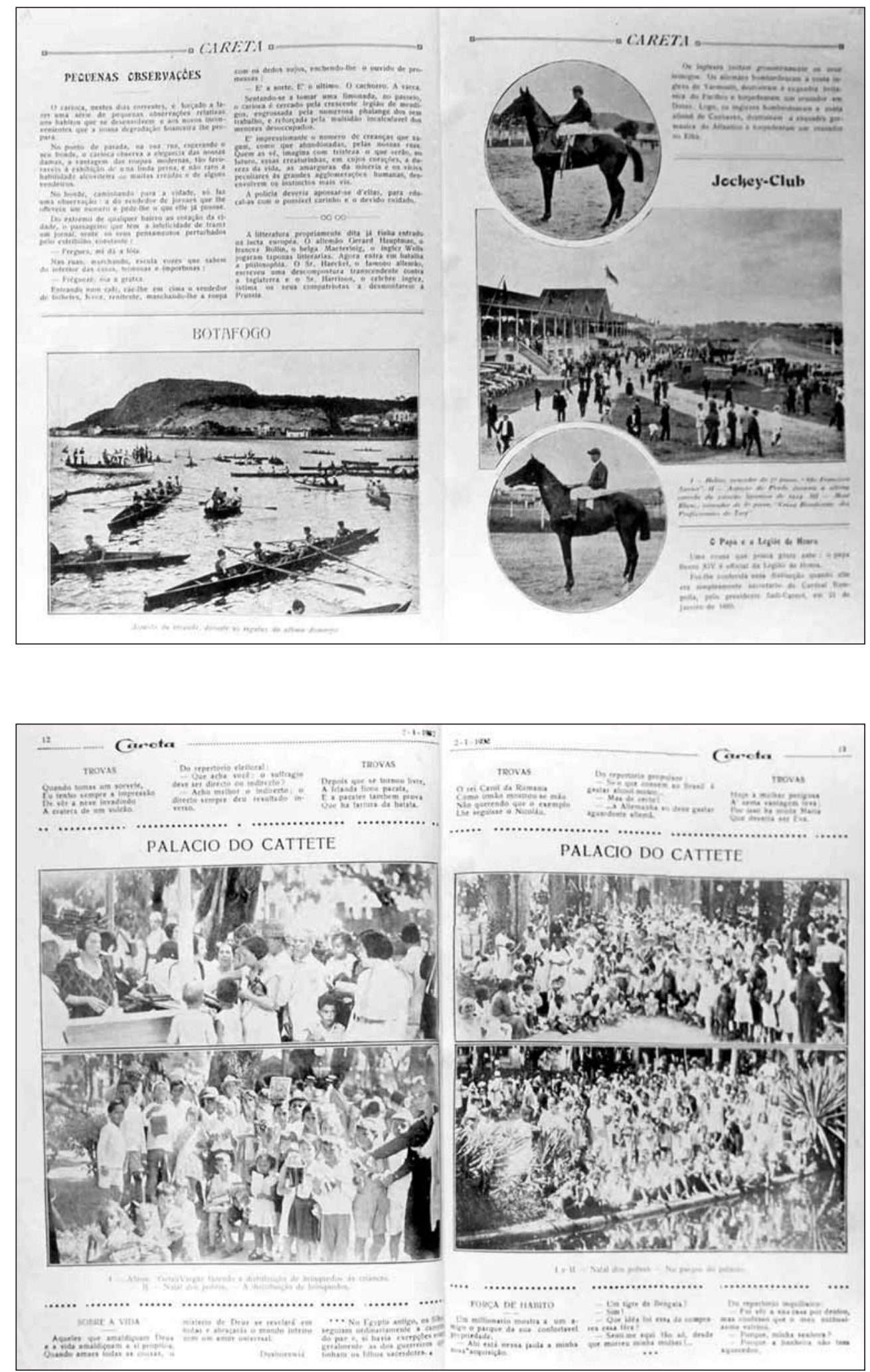

Annals of Museu Paulista. v. 13. n.1. Jan.-Jun. 2005. 

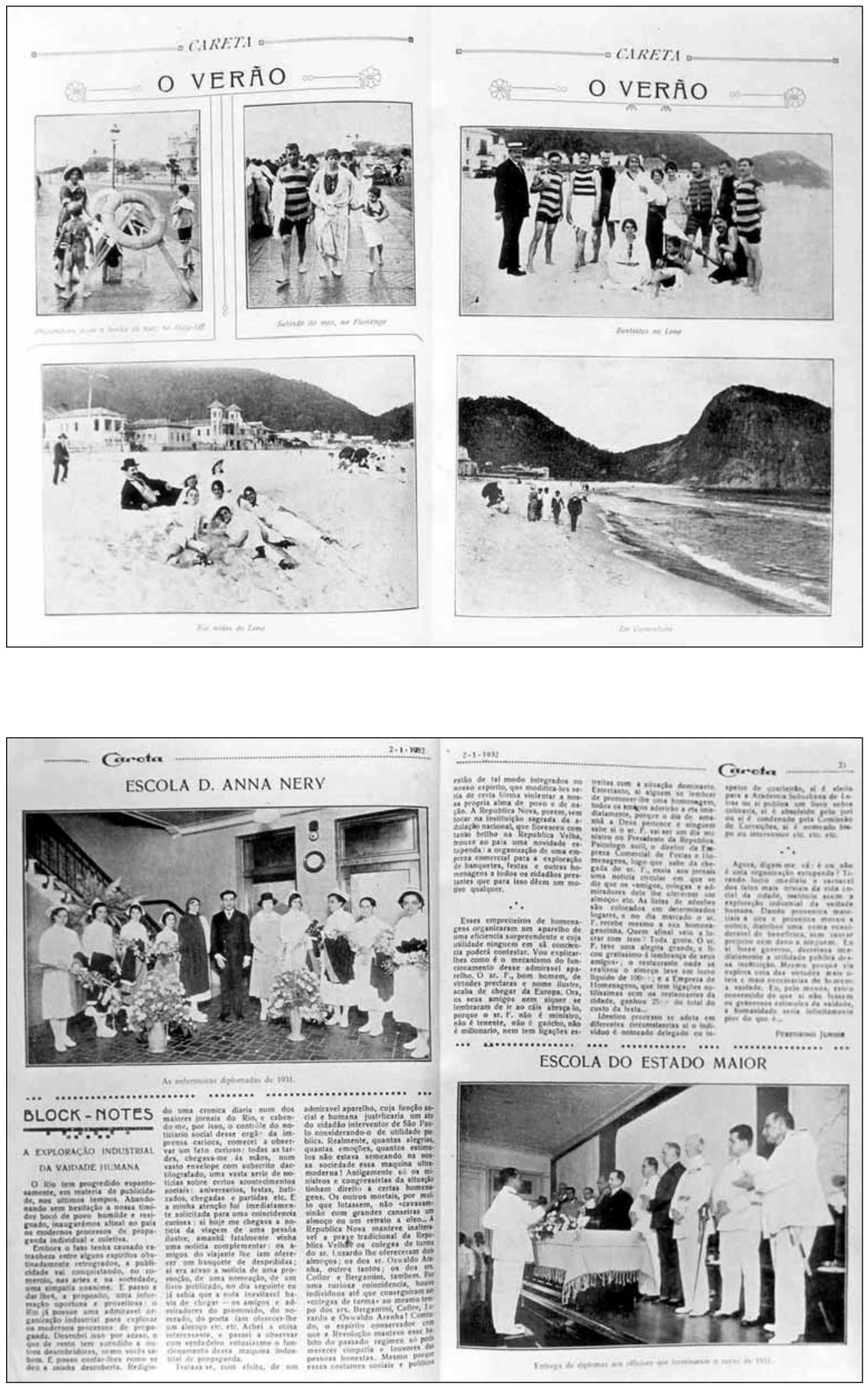

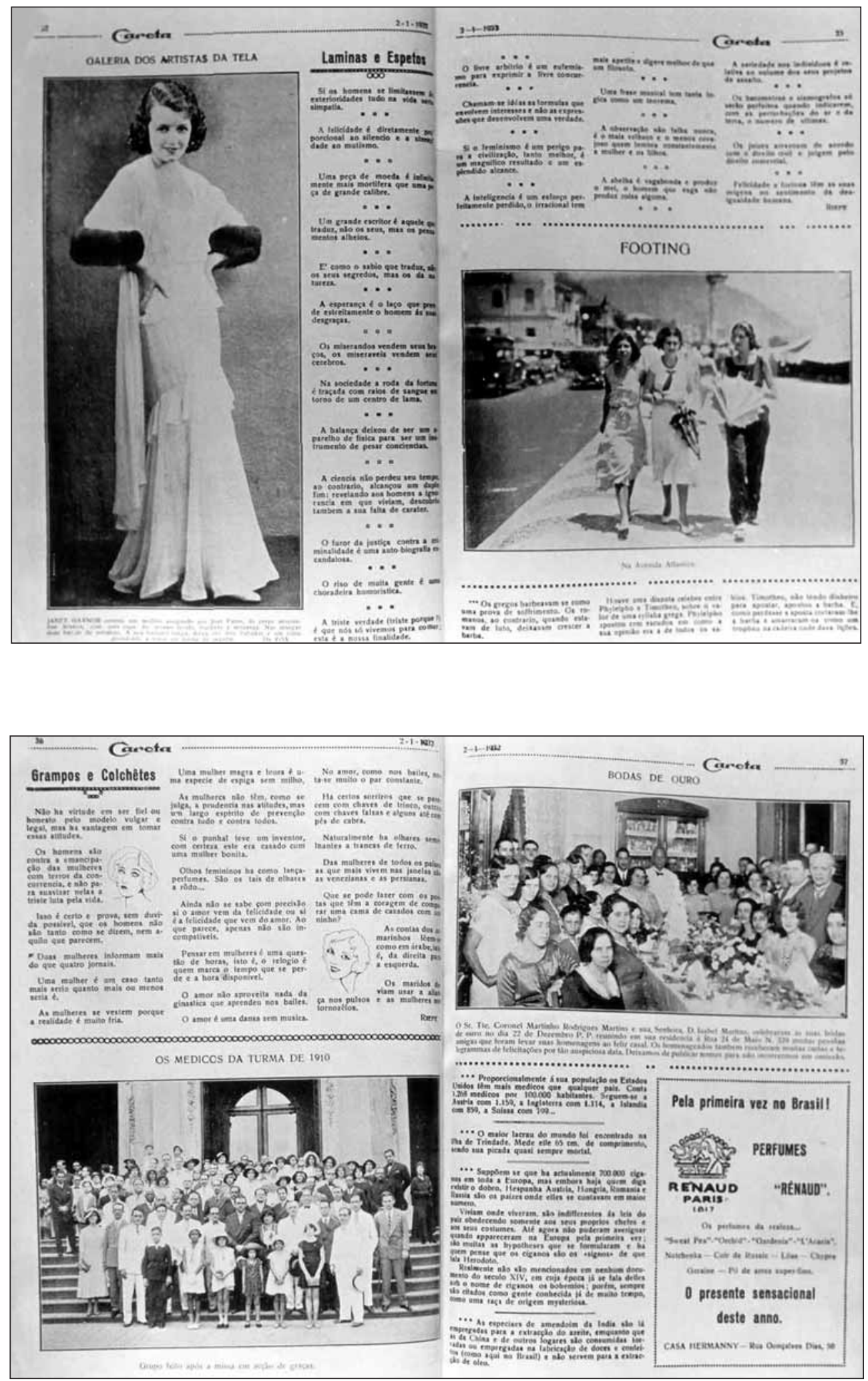

Annals of Museu Paulista. v. 13. n.1.Jan.-Jun. 2005. 
O Cruzeiro, 10/11/1928;4/12/1943; 7/1/1950.

A dinâmica das fotos em série vai definir 0 padrão do fotojornalismo de 0 Cruzeiro, que celebrava tanto 0 anonimato da massa e revelava a celebridade na vida comum quanto reafirmava o mundo da alta sociedade como o padrão da imagem ideal da vida burguesa.
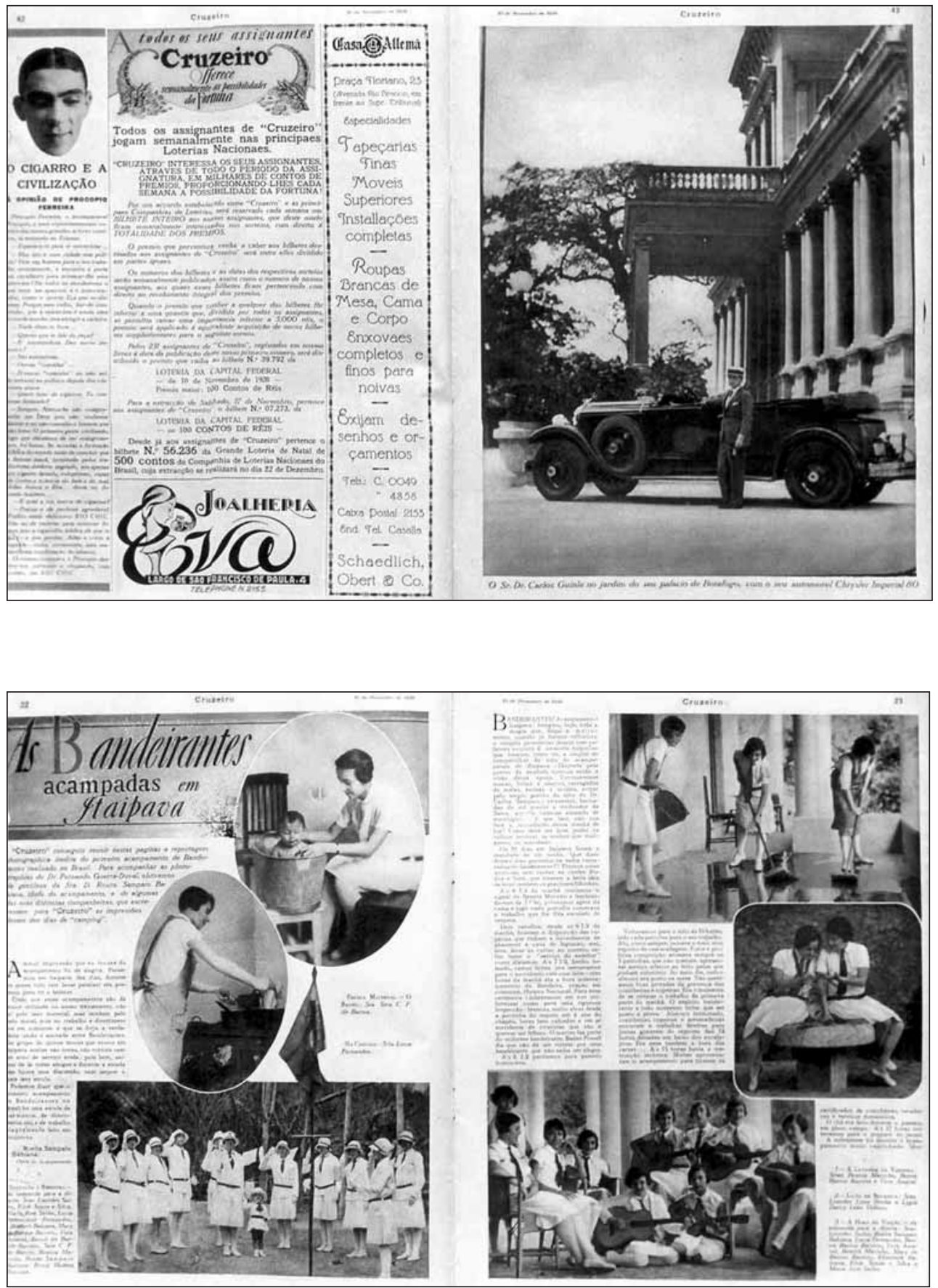

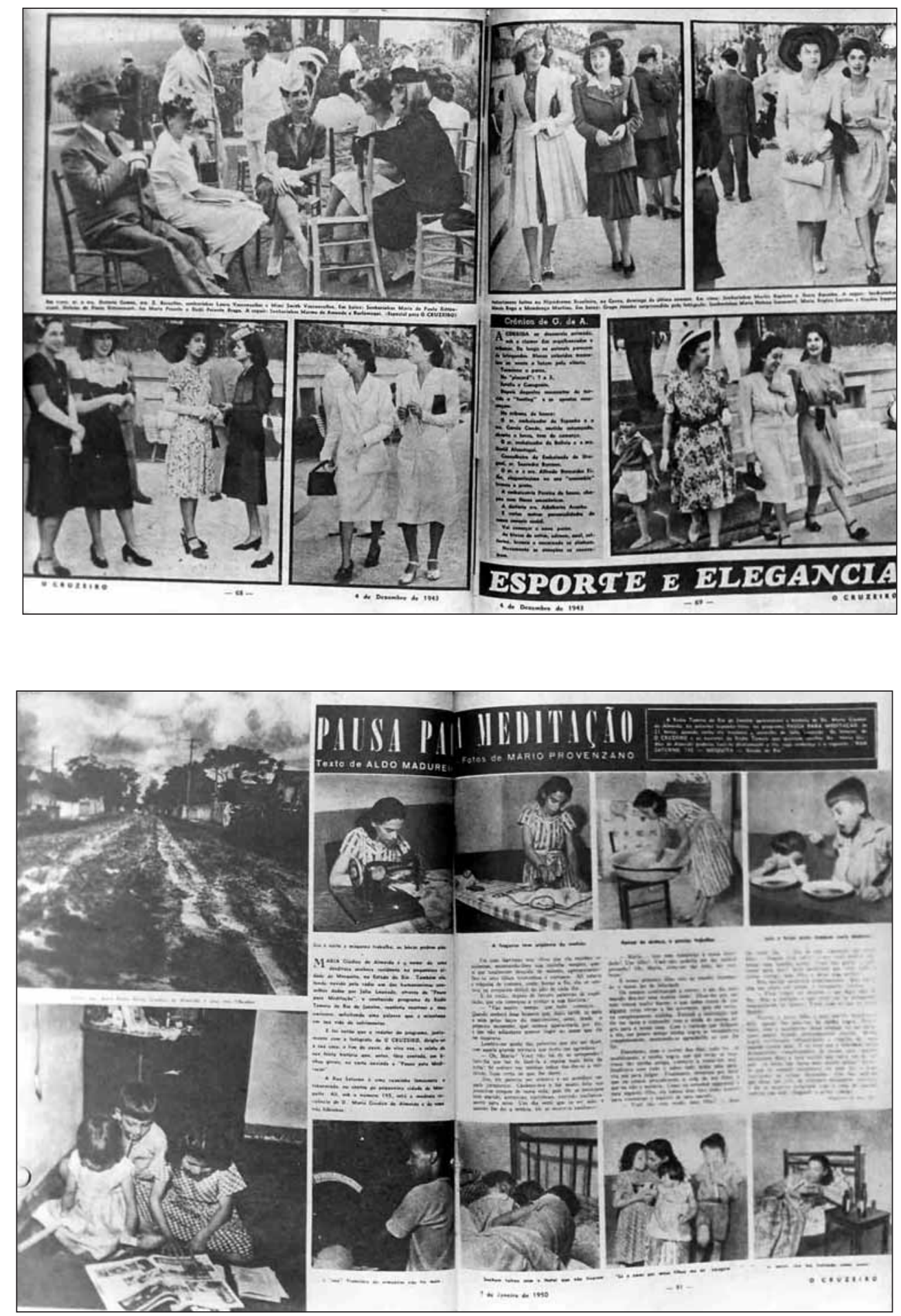

Annals of Museu Paulista. v. 13. n.1. Jan.-Jun. 2005. 
$\mathrm{N}$ esse sentido, o pobre é retratado como natura Imente pobre, e o rico como naturalmente rico, posto que em nenhum momento sã o representados fora do código dominante que associa um determinado espaço geográfico a certos objetos e pessoas, orientando com isso a própria representação dos eventos/ vivência dos grupos sociais. A ssim, a natura lizaçãa o do processo histórico, por meio da hegemonia da imagem fotog ráfica dominante, a tuou como elemento estruturante das representações socia is de comportamento que se instituíram ao longo da primeira metade do século XX, moldando os gostos e escolhas dos cidadãos que se tornavam consumidores.

As revistas ilustradas compuseram o catálogo de valores, emblemas, comportamentos e representações socia is pelo qual a burguesia se imaginou e se fez reconhecer, criando a utopia de um mundo digno, porque civilizado e empreendedor, e livre, porque acessível e transparente aos olhos de todos. A ima gem publicada torna-se o ícone, por excelência, de um modo de vida vitorioso, que prescinde da própria realização para existir, bastando para isso que as imagens fotográficas o reflitam.

Entre imagens...

Para concluir gostaria de colocar só uma última pergunta: como aprender por meio das imagens?

As ima gens são históricas, dependem das va riáveis técnicas e estéticas do contexto que as produziram e das diferentes visões de mundo que concorrem no jogo das relações sociais. No caso das fotografias, em suas diversas modalidades, elas guardam na sua superfície sensível a marca indefectível do passado que as produziu e consumiu. Um dia já foram memória presente, ou narrativa, próxima àqueles que as consumiam, possuíam, guardavam e colecionavam como relíquias, lembranças ou testemunhos. No processo de constante vir a ser recuperam o seu caráter de presença num novo lugar, num outro contexto e com uma função diferente. Da mesma forma que seus antigos produtores ou donos, a queles que as estudam como história entram em conta to com esse presente/ passado e os investem de sentido, um sentido diverso daquele dado pelos contemporâneos da imagem, mas próprio à problemática a ser estudada. $\mathrm{N}$ isso reside a competência daquele que analisa imagens do passado: no problema proposto e na construção do objeto de estudo. A imagem não fala por si só; é necessário que as perguntas sejam feitas.

A imagem decalca-se em nosso pensamento como sombras, duplos, projeções, representações, mensagens para sempre ou por um instante na memória, imediatamente ou a longo prazo, como se pensar fosse ver e ver fosse também pensar, numa circularidade difícil de interromper ${ }^{28}$. Reside aí a possibilidade de se conhecer por meio das imagens. 


\section{REFERÊN CIAS}

BARTHES, R.The Rethoric of image and The third meaning. Image, music, text. London: Fontana, 1977.

. Camara clara. Lisboa: Edições 70, 1980.

. Elementos de semiologia. Lisboa: Edições 70, 1989.

BOURDIEU, P. Photography:A middle brow art. London: Polity Press, 1990.

BURGIN, V. (Ed.). Thinking photography. London: Macmillan, 1982.

CAPRETTINI, G. P. Imagem. In: Enciclopédia Einaudi, Signo. Lisboa: Imprensa Nacional/Casa da Moeda, 1994, v. 31.

CARVALHO, V. C. et al. Fotografia e história: um ensaio bibliográfico. Anais do Museu Paulista, São Paulo, Nova Série, v. 2, 1994.

CARVALHO,V.C.; LIMA, S. F. Fotografias como objeto de coleção e de conhecimento. Anais do Museu Histórico Nacional, Rio de Janeiro, v. 32, 2000.

DARNTON, R. O beijo de Lamourette. São Paulo: Companhia das Letras, 1990.

DUBOIS, P. O ato fotográfico. Papirus: São Paulo, 1990.

ECO, U. As formas do conteúdo. São Paulo: Perspectiva, 1974.

FABRIS,A. Usos e funções da fotografia no século XIX. São Paulo: Edusp, 1995.

KN OWLES, C.; SWEETEMAN, P. (Eds.). Picturing the Social Landscape: visual methods and the sociological imagination. London/NY: Routledge, 2004.

LEITE, M. M. Retratos de família. São Paulo: Edusp, 1993.

MAUAD, A. M. Sob o signo da imagem:a produção da fotografia e o controle dos códigos de representação social pela classe dominanteno Rio de Janeiro, na primeira metade do século XX. 1990.2v. Tese (Doutorado em História) - Programa de Pós-Graduação em História Social, Universidade Federal Fluminense, Rio de Janeiro, 1990. (Publicada em 2003 em http://w w w.historia.uff.br/labhoi/tesdis.htm).

(Org.). Anais do Museu Histórico Nacional, Rio de Janeiro, v. 2, 2000.

.Apresentação (Fotografia). Anais do Museu Histórico Nacional, Rio de Janeiro, v. 32, 2000.

. A América é aqui: um estudo sobre a influência cultural norte-americana no cotidiano brasileiro (1930-1960). In:TORRES, S. (Org.). Raízes e rumos: perspectivas interdisciplinares em estudos americanos. Rio de Janeiro: 7Letras, 2001.

As três Américas de Carmem Miranda: cultura política e cinema no contexto da política da boa vizinhança. Transit circle: Revista Brasileira de Estudos Americanos, Rio de Janeiro, Abea/Contra-Capa, v. 1, Nova Série, 2002. 
MENESES, U.T. B. de. Fontes visuais, cultura visual, história visual. Balanço provisório, propostas cautelares. Revista Brasileira de História, São Paulo, v. 3, n. 45, p. 11-36, jul. 2003

NOSSO SÉCULO. São Paulo:Abril Culturala, 1980.

PANOFSKY, E. O significado nas artes visuais. 3 ed., São Paulo: Perspectiva, 1991.

SOLOMON-GODEAU, A. Photography at the dock: essays on Photography, institutions and practises. Minneapolis: University of Minnesota Press, 1991.

SONTAG, S. On Photography. Hardmondw orth: Penguin, 1977.

TAGG, J. The Burden of representation: essays on photographies and Histories. London: Macmillan, 1988.

TURAZZI, M. I. (Org.). Fotografia:Revista do Patrimônio Histórico eArtístico Nacional, Iphan, n. $27,1998$.

VILCHES, L. La lectura de la imagem:prensa, cine, tv. Barcelona: Ed. Paidós, 1992.

VOVELLE, M. Ideologia e mentalidades. São Paulo: Brasiliense, 1987.

Artigo apresentado em 08/2004. A provado em 09/2004. 